\title{
USPOREDBA PERCEPCIJE BLISKIH ODNOSA RODITELJA DJECE S TEŠKOĆAMA U RAZVOJU I RODITELJA DJECE NORMATIVNOG RAZVOJA
}

\section{A COMPARISON OF THE PERCEPTIONS OF CLOSE RELATIONSHIPS AMONG PARENTS OF CHILDREN WITH DEVELOPMENTAL DISABILITIES AND PARENTS OF CHILDREN WITH NORMATIVE DEVELOPMENT}

\author{
MIRA KLARIN ${ }^{1}$, VIŠNJA ČIRJAK ${ }^{2}$, SLAVICA ŠIMIĆ ŠAŠIĆ \\ 'University of Zadar, Zadar, Croatia, kontakt: mklarin@unizd.hr
}

${ }^{2}$ DV Latica, Zadar, Croatia

Primljeno/Received: 02.03.2020.

Prihvaćeno/Accepted: 14.10.2020.
Izvorni znanstveni rad/Original research article UDK: 364.64-056.3-053.2 doi: $10.31299 /$ hrri.56.2.
SAŽETAK: Cilj ovog istraživanja bio je usporediti bliske odnose dviju skupina roditelja, roditelja koji imaju dijete normativnog razvoja i roditelja koji imaju dijete s teškoćama u razvoju. U istraživanju je sudjelovalo ukupno 193 roditelja muške djece starosti od četiri do pet godina od čega je 116 roditelja djece normativnog razvoja $i 77$ roditelja djece $s$ teškoćama. U svrhu dobivanja odgovora na postavljena istraživačka pitanja korišteni su sljedeći mjerni instrumenti: Skala privrženosti kao stanja, Skala kvalitete obiteljskog funkcioniranja i Skala socijalne podrške, a obrada dobivenih podataka provedena je neparametrijskim statističkim postupcima. Rezultati istraživanja ukazuju na to da su bliski odnosi roditelja djece s teškoćama obilježeni većim traženjem sigurnosti. Kvaliteta obiteljskog funkcioniranja podjednaka je kod dvije skupine roditelja, dok roditelji djece s teškoćama u razvoju u manjoj mjeri dobivaju podršku prijatelja. Također rezultati ovog istraživanja idu u prilog zaključku da majke koje imaju dijete s teškoćom u većoj mjeri traže prisutnost bliskih osoba u odnosu na očeve iz te skupine roditelja. Dobiveni rezultati upućuju na važnost uzimanja u obzir obitelji kao sustava, osobito onih obitelji koji imaju dijete s teškoćom, što može uključivati različite programe s ciljem rada na obiteljskoj dinamici i partnerskim odnosima osobito u ranjivim obiteljima.

Ključne riječi: obrasci privrženosti, kvaliteta obiteljskog funkcioniranja, socijalna podrška, djeca normativnog razvoja, djeca s teškoćama
Abstract: The aim of this research was to compare the close relationships of two groups of parents, parents with a child of normative development and parents with a child with developmental disabilities. A total of 193 parents of 4- to 5-year-old male children participated in the study, of which 116 were parents of children of normative development and 77 parents of children with disabilities. The following measuring instruments were used to answer the research questions: State Adult Attachment Measure, Quality of Family Functioning Scale, and Social Support Scale. Non-parametric statistical procedures were used for data analysis. The results of the study indicate that close relationships among parents of children with disabilities are characterised by greater security-seeking. The quality of family functioning is the same for the two groups of parents, while parents of children with disabilities receive less support from friends. Also, the results of this study support the conclusion that mothers with a child with a disability are more likely to seek closeness from close others than fathers from the same group of parents. The findings indicate the importance of considering families as a system, especially those families with a child with a disability, which may include different programs aimed at working on family dynamics and partnerships, especially in vulnerable families.

Keywords: attachment patterns, quality of family functioning, social support, children of normative development, children with developmental disabilities 
Mira Klarin, Višnja Čirjak, Slavica Šimić Šašić: Usporedba percepcije bliskih odnosa roditelja djece s teškoćama u razvoju i roditelja djece...

\section{RODITELJSKI STRES U ODGOJU DJECE NORMATIVNOGA RAZVOJA I DJECE S TEŠKOĆAMA U RAZVOJU}

Roditeljstvo je izazovno i stresno iskustvo za svakoga čovjeka, bilo da se radi o odgoju djece normativnoga razvoja ili o odgoju djece s teškoćama u razvoju. U odnosu s djetetom roditelj uči razumjeti svoje dijete, razumjeti njegovo ponašanje, njegove namjere i njegove potrebe. $\mathrm{S}$ druge strane dijete $\mathrm{u}$ tom odnosu uči prepoznati namjere i perspektive svojih roditelja (Cuzzocrea, Larcan i Westh, 2013). Osobito je vidljiva kompleksnost odnosa roditelj dijete, ali i drugih odnosa u obiteljima u kojima je dijete s teškoćama u razvoju. ${ }^{1}$ Razina roditeljskog stresa u takvim obiteljima znatno je veća u odnosu na razinu stresa roditelja djece normativnog razvoja (Bluth, Roberson, Billen i Sams, 2013). Djeca s teškoćama u razvoju duže su ovisna o svojim roditeljima od djece normativnoga razvoja i zbog toga su istraživanja roditeljskog stresa i protektivnih/ rizičnih čimbenika iznimno važna za osnaživanje roditelja za ovu vrlo važnu ulogu (Hartley, Mailick Seltzer, Barker i Greenberg, 2011).

Oba roditelja djece s teškoćama u razvoju proživljavaju višu razinu stresa u odnosu na roditelje djece normativnoga razvoja (Cuzzocrea i sur., 2013; Bluth i sur., 2013.), ali čini se da je općenito značajno viša razina stresa kod majki (Esdaile i Greenwood, 2003; Scherer, Verhey i Kuper, 2019). Majke djece s teškoćom u razvoju proživljavaju niži stupanj roditeljskoga stresa i depresije u slučaju kada primaju veću društvenu podršku te zamjećuju vlastitu učinkovitost i osjećaju visoku razinu roditeljskoga zadovoljstva. Slično je i s očevima djece s teškoćom u razvoju. Oni proživljavaju viši stupanj roditeljskoga stresa kada osjećaju nisku razinu roditeljske učinkovitosti i zadovoljstva te u slučajevima težih teškoća u razvoju djeteta (Wanamaker i Glenwick, 1998).

S vremenom povišeni roditeljski stres uzrokuje i više poremećaja u ponašanju djeteta, a ponašajni

1 Učenik s teškoćama u razvoju jest učenik čije sposobnosti u međudjelovanju s čimbenicima iz okoline ograničavaju njegovo puno, učinkovito i ravnopravno sudjelovanje u odgojno-obrazovnom procesu s ostalim učenicima, a proizlaze iz: tjelesnih, mentalnih, intelektualnih, osjetilnih oštećenja i poremećaja funkcija - kombinacije više vrsta gore navedenih oštećenja i poremećaja. (NN, 23/91)

\section{PARENTAL STRESS IN THE UPBRINGING OF CHILDREN WITH NORMATIVE DEVELOPMENT AND CHILDREN WITH DEVELOPMENTAL DISABILITIES}

Parenting is a challenging and stressful experience for every person, whether it includes raising children with normative development or children with disabilities. In the parent-child relationship the parent learns to understand the child as well as his or her behaviour, intentions and needs. On the other hand, the child learns to recognise the intentions and perspectives of his or her parents (Cuzzocrea, Larcan, \& Westh, 2013). The complexity of the parent-child relationship and of other relationships as well is especially visible in families with a child with disabilities ${ }^{1}$. The level of parental stress in such families is significantly higher than the level of stress of parents of children of normative development (Bluth, Roberson, Billen, \& Sams, 2013). Children with disabilities are more dependent on their parents than children of normative development; therefore, research on parental stress and protective/risk factors is extremely important for empowering parents for this very important role (Hartley, Mailick Seltzer, Barker \& Greenberg, 2011).

Both parents of children with disabilities experience higher levels of stress than parents of children with normative development (Cuzzocrea et al., 2013; Bluth et al., 2013), but mothers generally appear to have significantly higher levels of stress (Esdaile \& Greenwood, 2003; Scherer, Verhey, \& Cooper, 2019). Mothers of children with disabilities experience a lower level of parental stress and depression when they receive greater social support and notice their own effectiveness and feel a high level of parental satisfaction. It is similar with the fathers of children with disabilities. They experience a higher degree of parental stress when they feel low levels of parental effectiveness and satisfaction, as well as in cases of severe child developmental difficulties (Wanamaker \& Glenwick, 1998).

Over time, increased parental stress also leads to more disruptive behaviour of the child, and behavioural problems adversely affect the already increased parental stress. The appearance of a so-called double diagnosis is a particularly difficult challenge for families with children with disabili- 
problemi negativno utječu na već povećani roditeljski stres. Pojava tzv. dvostruke dijagnoze predstavlja posebno velik izazov obiteljima s djecom s teškoćama u razvoju budući da se uz teškoće često razvijaju i poremećaji u ponašanju. Problemi u ponašanju djece s raznim teškoćama i kašnjenjima u razvoju veći su i učestaliji nego kod djece normativnoga razvoja. Viša zastupljenost poremećaja u ponašanju (agresija, depresija, anksioznost, problemi sa spavanjem, samoozljeđivanje i sl.) djece s teškoćama u razvoju u odnosu na djecu normativnoga razvoja zamijećena je već na predškolskoj razini (Baker, Mcintyre, Blacher, Crnic, Edelbrock, Low, 2003). Budući da roditelji djece s teškoćama u razvoju uglavnom razviju vještine i pronađu načine uspješnoga nošenja s djetetovom razvojnom teškoćom, ponašajni problemi predstavljaju mnogo veći izvor roditeljskoga stresa (Baker, Blacher i Olsson, 2005). Mnoga istraživanja potvrđuju kako je veća razina problema u ponašanju djece izravno pozitivno povezana s roditeljskim stresom i roditeljskim osjećajem učinkovitosti obaju roditelja (Wanamaker i Glenwick, 1998; Baker i sur., 2003). Isto tako veća razina roditeljskog stresa povezana je s lošijim obiteljskim funkcioniranjem mjerenim putem obiteljske kohezije (Milić Babić, 2012).

Zbog značajnosti utjecaja roditeljskoga stresa na kvalitetu života roditelja i napredak njihove djece s teškoćama u razvoju, mnogi istraživači ističu važnost programa podrške obiteljima djece s teškoćama kako bi se poboljšala kvaliteta odnosa roditelja i djeteta, ali i kako bi se snizila razina roditeljskog stresa i time olakšao razvoj djeteta (Esdaile i Greenwood, 2003; Milić Babić, 2012).

\section{BLISKI ODNOSI RODITELJA DJECE NORMATIVNOGA RAZVOJA I DJECE S TEŠKOĆAMA U RAZVOJU}

Najveći fokus u istraživanjima kvalitete odnosa u obiteljima jest na odnosu roditelja i djeteta, na partnerskim odnosima te na obiteljskom funkcioniranju. Kada se uspoređuje partnerski odnos roditelja djece normativnoga razvoja i roditelja djece s teškoćama u razvoju, najčešće se istražuje mentalno zdravlje roditelja, roditeljski stres i njihova učinkovitost kao roditelja (Kersh, Hedvat, Hauser-Cram i Warfield, 2006). Govoreći o mentalnomu zdravlju roditelja, prva istraživanja bavila ties, as the development of behavioural problems often goes along with disabilities. Behavioural problems of children with various disabilities and developmental delays are greater and more frequent than in children of normative development. A higher prevalence of behavioural disorders (e.g. aggression, depression, anxiety, sleep problems, self-harm) of children with disabilities in relation to children of normative development is already observed at the preschool level (Baker, Mcintyre, Blacher, Crnic, Edelbrock, \& Low , 2003). Since parents of children with disabilities mainly develop skills and find ways to successfully cope with the child's developmental disabilities, behavioural problems represent a much greater source of parenting stress (Baker, Blacher i Olsson, 2005). Many studies confirm that a greater amount of children's behavioural problems are directly related to parental stress and the sense of parental effectiveness of both parents (Wanamaker \& Glenwick, 1998; Baker et al., 2003). Likewise, parental stress is associated with poorer family functioning measured as family cohesion (Milić Babić, 2012).

Due to the importance of the impact of parental stress on the quality of life of parents and the progress of their children with disabilities, many researchers stress the importance of educational support programs for families with children with disabilities to improve the quality of parent-child relationships and, also, to reduce parental stress and thus facilitate the child's development (Esdaile \& Greenwood, 2003; Milić Babić, 2012).

\section{THE CLOSE RELATIONSHIPS OF PARENTS WITH CHILDREN OF NORMATIVE DEVELOPMENT AND CHILDREN WITH DEVELOPMENTAL DISABILITIES}

The largest focus in research on the quality of relationships in families in general is put on the parent-child relationship, the partner relationship, and family functioning. When comparing the partner relationship of parents of normative and developmentally disabled children, the mental health of parents, parental stress and their effectiveness as parents are most commonly studied (Kersh, Hedvat, Hauser-Cram, \& Warfield, 2006). When speaking of parents' mental health, previous research has addressed the grief and 
su se tugom i tjeskobom roditelja djece s teškoćama u razvoju, a kasnija su se usmjerila na simptome depresije roditelja. Jedan dio takvih istraživanja utvrdio je višu zastupljenost simptoma depresije (Scherer i sur. 2019; Bleacher, Shapiro, Lopez i Diaz, 1997), veću razinu depresivnosti i anksioznosti (Raj Gogoi, Kumar, Pereira Deuri, 2016) kod majki djece s teškoćama u razvoju u usporedbi s majkama djece normativnog razvoja te veću učestalost negativnih emocija i somatskih simptoma (Ha, Greenberg i Seltzer, 2011). Scherer i sur. (2019) ističu da veću razinu depresivnosti majki koje imaju dijete s teškoćama u odnosu na očeve možemo objasniti većom odgovornošću majki za odgoj djeteta, ali možda i tendencijom očeva da prikriju depresivne simptome tijekom samoprocjene. Druga skupina istraživanja ove pojavnosti opovrgnula su postojanje razlika između majki djece normativnog razvoja i majki djece s teškoćama u razvoju (Bristol, Gallagher i Schopler, 1998). Također nije pronađena značajna razlika u ovim dvjema skupinama roditelja s obzirom na pozitivne emocije (Ha, Greenberg i Seltzer, 2011). Istraživanja mentalnoga zdravlja očeva i majki utvrdila su kako se u simptomi depresije u većoj mjeri pojavljuju kod majki (Bristol i sur., 1998).

Usporedba kvalitete partnerskog odnosa u obiteljima djece s teškoćama u razvoju i u obiteljima djece normativnog razvoja pokazala je nekonzistentne rezultate. Dok pojedini nalazi upućuju na viši stupanj nezadovoljstva partnerskim odnosom kod majki djece s teškoćama u razvoju, drugi nalazi opovrgavaju razlike u odnosu na majke djece normativnog razvoja. Povezanost kvalitete partnerskog odnosa i psihološke dobrobiti majki i očeva u obiteljima djece s teškoćama u razvoju još uvijek nije dovoljno istražena, no čini se da kvaliteta partnerskog odnosa snažnije utječe na roditeljstvo nego vanjski izvori društvene podrške (Kersh i sur., 2006).

Mnogi očevi žele biti više uključeni u njegu i brigu o svojoj djeci koja imaju teškoće u razvoju, no osjećaju nesigurnost i svoje vještine za zbrinjavanje djeteta procjenjuju nedovoljnima. Očevi se često osjećaju nepoželjnim sudionicima zbrinjavanja čak i kada su uključeni u programe rane intervencije (Hornby, 1992; Lamb i Billings, 1997; Quinn, 1999; Kersh i sur., 2006). anxiety of parents of children with disabilities, and more recent research has focused on the symptoms of parental depression (Scherer et al., 2019; Bleacher, Shapiro, Lopez \& Diaz, 1997), higher prevalence of depression and anxiety (Raj Gogoi, Kumar, \& Pereira Deuri, 2016) and negative emotions and somatic symptoms (Ha, Greenberg, \& Seltzer, 2011) in mothers of children with disabilities compared to mothers of children of normative development. Scherer et al. (2019) point out that a higher level of depression of mothers who have a child with difficulties compared to fathers can be explained by the greater responsibility of mothers for raising a child and perhaps also the tendency of fathers to conceal depressive symptoms during self-assessment. Another group of research has refuted the existence of differences between mothers of children of normative development and mothers of children with disabilities (Bristol, Gallagher, \& Schopler, 1998). These two groups of mothers also do not show significant differences in positive emotions (Ha, Greenberg \& Seltzer, 2011). Mental health studies of fathers and mothers have found that symptoms of depression appear more frequently in mothers (Bristol et al., 1998).

Comparisons of the quality of marital relationships in the families of children with disabilities and in the families of children with normative development have shown inconsistent results. While some findings suggest a higher degree of dissatisfaction with the marital relationship in mothers of children with disabilities, other findings deny differences compared to mothers of children with normative development. The relationship between the marital relationship and psychological well-being of mothers and fathers in families of children with disabilities has not yet been sufficiently examined; nevertheless, evidence suggests that the quality of the partnership seems to have a stronger impact on parenting than external sources of social support (Kersh et al., 2006).

Many fathers want to be more involved in the care for their children with developmental disabilities, but feel insecure and view their child care skills as inadequate. Fathers often feel like unwanted caregivers even when they are involved in early intervention programs (Kersh et al., 2006; Hornby, 1992; Lamb \& Billings, 1997; Quinn, 1999).

Marital/partnership quality is the most important component affecting the well-being of parents of 
Kvaliteta partnerske veze najvažnija je komponenta koja utječe na dobrobit roditelja djece $\mathrm{s}$ teškoćama u razvoju (Kersh i sur., 2006). Roditelji koji imaju dijete s teškoćom u razvoju mogu se osjećati jako povezano i to može dodatno učvrstiti njihov partnerski odnos, dok je za neke druge roditelje dijete s teškoćom u razvoju velik teret za njihovu bračnu vezu (Heiman, 2002).

Usporedbom obiteljske uloge očeva i majki i obiteljske dinamike u obiteljima muške djece $s$ teškoćom u razvoju i muške djece normativnog razvoja pokazala je da majke obiju skupina imaju više simptoma depresije i pokazivale su viši stupanj nezadovoljstva obiteljskom dinamikom. U usporedbi s očevima dječaka normativnoga razvoja, očevi dječaka s teškoćama u razvoju manje su svakodnevno brinuli o svojim sinovima jer su zbrinjavali djecu normativnoga razvoja (Bristol i sur., 1988). Roditelji dječaka s teškoćama u razvoju imali su više bračnih problema od roditelja dječaka normativnog razvoja. Ovi roditelji, a posebice očevi, u većoj su se mjeri žalili na poteškoće u braku i teže odgovarali na djetetove potrebe.

Sljedeći aspekt bliskih odnosa ogleda se u obiteljskom funkcioniranju. Sigurno je da je zadovoljstvo partnerskim odnosom povezano s obiteljskom dinamikom i funkcioniranjem obitelji. Obitelj koja ima dijete s teškoćama u razvoju često prolazi kroz razdoblja nestabilnosti i neusklađenosti. Rođenje djece s teškoćama u razvoju može utjecati na komunikaciju, rješavanje problema, zadovoljstvo i opće funkcioniranje obitelji (Iacolinoa, Pellerone Pacea, Ramacia i Castorina, 2016). Pronalaženjem adaptivnih načina nošenja sa stresom roditelji pridonose prilagodbi cijele obitelji. Adaptivni načini nošenja sa stresom povezani su sa psihološkom dobrobiti roditelja (Hartley, Mailick Seltzer, Barker i Greenberg, 2011) te time sigurno značajno pridonose pozitivnoj obiteljskoj klimi. Međutim isto tako važno je istaknuti da na obiteljsko funkcioniranje značajno utječe teškoća koju dijete ima. Također dijete s teškoćom može biti izvorom anksioznosti, izrazite zaštićenosti i rigidnosti roditelja što dalje može objasniti nižu razinu koherentnosti i slabije usmjerenosti roditelja na razvoj drugih članova obitelji (Cuzzocrea i Larcan, 2013). Prilagođavajući se povećanim zahtjevima djeteta s teškoćama, zanemaruju se potrebe drugih članova obitelji (Milić children with disabilities (Kersh et al., 2006). Some parents with a child with disabilities may feel strongly connected and this can further strengthen their marital relationship, while for some other parents, a child with a developmental disability may be a great burden on their marital relationship (Heiman, 2002).

Comparison of the family role of mothers and fathers and the family dynamics in families with male children with disabilities and male children of normative development showed that mothers of both groups had more symptoms of depression and showed higher levels of dissatisfaction with the family dynamics. Compared to the fathers of boys of normative development, fathers of boys with disabilities cared less about their sons on a daily basis because they cared for children of normative development (Bristol et al., 1988). Parents of boys with disabilities had more marital problems than parents of boys of normative development. These parents, especially the fathers, complained to a greater extent about the difficulties of marriage and had more difficulties in responding to their child's needs.

Another aspect of close relationships is reflected in family functioning. It is certain that satisfaction with a partnership is related to family dynamics and family functioning. A family with a child with developmental disabilities often goes through periods of instability and inconsistency. The birth of children with disabilities can affect communication, problem-solving, satisfaction, and general family functioning (Iacolinoa, Pellerone Pacea, Ramacia, $\&$ Castorina, 2016). By finding adaptive ways to deal with stress, parents contribute to the adjustment of the whole family. Adaptive ways of coping with stress are associated with the psychological well-being of parents (Hartley, Mailick Seltzer, Barker, \& Greenberg, 2011) and, thus, certainly contribute significantly to a positive family climate. However, it is also important to point out that family functioning is significantly affected by the child's disability. Also, a child with a disability may be a source of parental anxiety, extreme protection, and rigidity, which may further explain the lower level of coherence and lower parental focus on the development of other family members (Cuzzocrea \& Larcan, 2013). While adapting to the increased demands of a child with disabilities, the needs of other family members are neglected (Milić Babić, 
Babić, 2012). Različita razina konflikta, kohezije, adaptabilnosti i organizacije može dati odgovor na pitanje zašto se neke obitelji lakše, a neke teže nose s poteškoćama i povećanim zahtjevima koje nosi život s djetetom s teškoćama (Cuzzocrea, Larcan, Baiocco i Costa, 2011).

\section{SOCIJALNA PODRŠKA}

Socijalna podrška roditeljstvu izuzetno je važan zaštitni čimbenik u nošenju s različitim stresorima povezanim s roditeljstvom općenito (Milić Babić, 2019). Socijalna podrška između ostalog povećava fleksibilnost roditelja i time smanjuje rizik od depresivnosti i anksioznosti (Scherer i sur., 2019). Prisutnost djeteta s teškoćama u obitelji mijenja roditeljske zahtjeve te obiteljsku dinamiku. Samim time u ovakvim obiteljima postoje povećani zahtjevi za razvojem dodatnih kapaciteta svakog člana obitelji, ali i za dodatnom pomoći izvan obitelji. Socijalna podrška mogla bi se definirati kao socijalno međudjelovanje koje se odnosi na međusobno pomaganje većeg broja osoba (Janković, 2008). Roditelji koji izvješćuju o visokoj razini socijalne podrške, učinkovitiji su u rješavanju problema i psihološku dobrobit procjenjuju boljom u odnosu na roditelje koji socijalnu podršku procjenjuju slabije. Socijalna podrška obitelji i prijatelja pridonosi korištenju adaptivnih mehanizama potrebnih u nošenju sa stresom koji je povezan i s odnosom roditelj - dijete i s partnerskim odnosom (Hartley i sur., 2011). Ispitujući povezanost između socijalne podrške i nekih aspekata roditeljstva u obiteljima $\mathrm{s}$ djecom s teškoćama u razvoju, Leutar i Oršulić (2015) ističu da je roditeljima na prvom mjestu po važnosti podrška obitelji i to osobito podrška supružnika. Nakon supružničke podrške po važnosti se ističe podrška drugih članova obitelji, a potom prijatelja i rodbine. Na posljednjem je mjestu institucionalna podrška. Supružnik je na prvom mjestu traženja socijalne podrške i to one emocionalne, financijske i praktične. Autorice zaključuju da je obitelj najveći izvor sigurnosti i podrške roditeljima djece s teškoćama u razvoju. Majke djece $\mathrm{s}$ teškoćama primale su manje rekreativne podrške (vremena posvećenoga supružnicima kao temelj za izgradnju emocionalne podrške) u odnosu na majke djece normativnoga razvoja, no majke iz obiju skupina izjasnile su se kako primaju manju
2012). Different levels of conflict, cohesion, adaptability, and organisation may provide an answer to the question of why some families cope more easily and some with more difficulties to the increased demands of living with a child with disabilities (Cuzzocrea, Larcan, Baiocco, \& Costa, 2011).

\section{SOCIAL SUPPORT}

Social support to parenting is an extremely important protective factor in dealing with various stressors related to parenting in general (Milić Babić, 2019). Social support, among other things, increases the flexibility of parents and thus reduces the risk of depression and anxiety (Scherer et al., 2019). The presence of a child with disabilities in the family changes parental requirements and family dynamics. Therefore, in such families there are not only increased demands for the development of additional capacities of each family member, but also for additional assistance outside the family. Social support could be defined as social interaction that refers to mutual assistance of a larger number of people (Janković, 2008). Parents who report high social support are more effective in solving problems and assess psychological well-being better compared to parents who report lower social support. Social support from family and friends contributes to the use of adaptive mechanisms required in dealing with stress that is associated with both the parent-child relationship and the partnership (Hartley et al., 2011). In examining the relationship between social support and some aspects of parenting in families with children with disabilities, Leutar and Oršulić (2015) point out that family support is the most important for parents, especially the support of their spouses. After spousal support, the importance of the support of other family members and then friends and relatives is emphasised. Institutional support is in the last place. The spouse is in the first place for seeking social, emotional, financial and practical support. The authors conclude that the family is the greatest source of security and support for parents of children with disabilities. Mothers of children with disabilities received less recreational support (time devoted to spouses as a basis for building emotional support) compared to mothers of children of normative development. Mothers from both groups stated that they provide a greater extent of emotional support 
emocionalnu potporu od supružnika u odnosu na onu koju one njima pružaju (Bristol i sur., 1988).

U ovom istraživanju fokus smo stavili na percepciju bliskih odnosa u obiteljima koje imaju dijete s teškoćama i obiteljima koje imaju dijete normativnog razvoja. U tom kontekstu uključili smo varijablu privrženost u bliskim odnosima roditelja. Ti odnosi ne moraju uključiti partnera. Naime, u nekim obiteljima nedostaje jedan roditelj, stoga su odnosi s drugim značajnim osobama u životu roditelja vrlo važni. Privrženost u bliskim odnosima i usporedba privrženosti roditelja koji imaju dijete s teškoćama s roditeljima koji imaju dijete normativnog razvoja manje je istraživana, stoga smatramo da je promatranje ove varijable značajan doprinos istraživanju ovog područja. Kvaliteta obiteljskog funkcioniranja i socijalna podrška obitelji i prijatelja sljedeće su varijable koje ispituju bliske odnose roditelja s njima važnim osobama.

S obzirom na relativno malo istraživanja kojima je cilj ispitivanje bliskih odnosa i obiteljske dinamike obitelji koje imaju dijete s teškoćama i usporedba s dinamikom obitelji koje nemaju dijete $\mathrm{s}$ teškoćama, cilj je ovog istraživanja usporedba percepcije bliskih odnosa roditelja djece s teškoćama u razvoju i roditelja koji nemaju dijete s teškoćama u razvoju. Pritom smo percepciju bliskih odnosa mjerili uz pomoć tri varijable. Jedna mjeri trenutno stanje privrženosti u bliskim odnosima kroz traženje emocionalne sigurnosti i blizine s jedne strane i tendenciju izbjegavanja bliskosti s druge strane. Druga varijabla mjeri procjenu kvalitete obiteljskog funkcioniranja između članova obitelji i obitelji u cjelini. Treća varijabla koja mjeri odnos roditelja s bliskim osobama mjera je primljene općenite socijalne podrške od članova obitelji i od prijatelja. Stoga smo definirali sljedeća istraživačka pitanja:

1. ispitati postoje li razlike u obrascima privrženosti u bliskim odnosima između roditelja koji imaju djecu normativnog razvoja i roditelja koji imaju djecu s teškoćama u razvoju,

2. ispitati postoji li razlika u obrascima privrženosti u bliskim odnosima očeva u odnosu na majke,

3. ispitati postoji li razlika u procjeni kvalitete obiteljskog funkcioniranja između obitelji djece normativnog razvoja i obitelji djece s teškoćama u razvoju, to their spouses compared to the emotional support they receive from them (Bristol et al. 1988).

In this study, we focused on the perception of close relationships in families with a child with disabilities and families with a child of normative development. In this context, we included the variable of attachment in close parental relationships. These relationships do not have to involve a partner. Namely, in some families one parent is missing, so the relationships with other important people in the life of the parents are very important. The attachment in close relationships and the comparison of the attachment of parents who have a child with disabilities with parents who have a child of normative development is less researched, so we believe that observing this variable is a significant contribution to research in this area. The quality of family functioning and the social support of family and friends are the following variables that examine parents' close relationships with important people.

Considering the relatively small amount of research aimed at examining the close relationships and family dynamics of families with children with disabilities and comparing them with the dynamics of families without children with disabilities, the aim of this study was to compare the perceptions of close relationships of parents with children with disabilities and parents who do not have a child with disabilities. In doing so, we measured the perception of close relationships with the help of three variables. One measures the current state of attachment in close relationships through the search for emotional security and closeness on the one hand and the tendency to avoid intimacy on the other. The second variable measures the assessment of the quality of family functioning between family members and the family as a whole. The third variable is a measure of generally received social support from family members and friends. Therefore, we defined the following research questions:

1. To examine whether there are differences in attachment patterns in the close relationships between parents who have children of normative development and parents who have children with disabilities.

2. To examine whether there is a difference in the attachment patterns in close relationships of fathers in comparison with mothers. 
4. ispitati postoji li razlika u procjeni kvalitete obiteljskog funkcioniranja između očeva i majki,

5. ispitati postoji li razlika u percepciji primljene socijalne podrške od članova obitelji i prijatelja u obiteljima djece s teškoćama u razvoju u odnosu na obitelji djece normativnog razvoja,

6. ispitati postoji li razlika u percepciji primljene socijalne podrške od članova obitelji i prijatelja između očeva i majki.

Hipoteze su od kojih polazimo sljedeće:

1. Postoje razlike u obrascima privrženosti u bliskim odnosima između roditelja koji imaju djecu normativnog razvoja i roditelja djece koja imaju djecu s teškoćama u smjeru naglašenije privrženosti bliskim osobama roditelja djece s teškoćama sukladno njihovim povećanim potrebama za sigurnošću, traženjem blizine i zbližavanjem s bliskim osobama.

2. Postoji razlika u obrascima privrženosti u bliskim odnosima očeva u odnosu na majke u smjeru izraženije tendencije majki prema emocionalnim povezivanjem s bliskim osobama.

3. Kvaliteta obiteljskog funkcioniranja različita je u obiteljima djece normativnog razvoja u odnosu na obitelji djece s teškoćama u razvoju u smjeru slabije kvalitete obiteljskog funkcioniranja obitelji koje imaju dijete s teškoćama.

4. Očekujemo da će očevi kvalitetu obiteljskog funkcioniranja procijeniti boljom u odnosu na majke o obzirom da, kako pokazuju rezultati istraživanja, majke preuzimaju veću odgovornost u odnosu na odgoj djeteta.

5. Postoji razlika u percepciji primljene socijalne podrške od članova obitelji i prijatelja u obiteljima djece s teškoćama u razvoju u odnosu na obitelji djece normativnog razvoja u smjeru manje primljene socijalne podrške u obiteljima $\mathrm{s}$ djetetom $\mathrm{s}$ teškoćama.

6. S obzirom na doživljaj veće odgovornosti majke prema odgoju djeteta očekujemo da će majke biti manje zadovolje potencijalnom raspoloživošću socijalne podrške obitelji i prijatelja.

\section{METODA ISTRAŽIVANJA}

\section{Sudionici i postupak istraživanja}

U istraživanju su sudjelovale dvije skupine roditelja. Prvu skupinu činili su roditelji djece s
3. To examine whether the quality of family functioning is different in the families of children of normative development compared to the families of children with disabilities.

4. Examine whether there is a difference in the assessment of the quality of family functioning between fathers and mothers.

5. To examine whether there is a difference in the perception of received social support from family members and friends in the families of children with disabilities compared to the families of children of normative development.

6. Examine whether there is a difference between fathers and mothers in the perception of social support received from family members and friends. The hypotheses were the following:

1. There are differences in attachment patterns in the close relationships between parents who have children of normative development and parents who have children with disabilities in the direction of a greater attachment among parents of children with disabilities in accordance with their increased needs for security and seeking closeness and rapprochement with close people.

2. There is a difference in the attachment patterns in close relationships of fathers in comparison with mothers in the direction of a greater tendency of mothers for emotional connection with close persons.

3. The quality of family functioning is different in the families of children of normative development compared to the families of children with disabilities in the direction of poorer quality of family functioning of families who have a child with disabilities.

4. We expect that fathers will assess the quality of family functioning better than mothers, given that, according to research results, mothers take greater responsibility in raising a child.

5. There is a difference in the perception of received social support from family members and friends in the families of children with disabilities compared to the families of children of normative development in the direction of less received social support in families with a child with disabilities.

6. Given the experience of greater responsibility of the mother towards the upbringing of the child, we expect that mothers will be less satisfied 
teškoćama u razvoju, a drugu roditelji djece normativnog razvoja. Ciljana skupina bili su roditelji muške djece u dobi od četiri do pet godina starosti. Prvu skupinu činili su dječaci koji imaju objektivnu dijagnozu neke od teškoća u razvoju. Ovu skupinu dječaka, različitih teškoća u razvoju, čine polaznici jednog vrtića u kojem se provode različiti edukacijsko-rehabilitacijski programi za djecu rane i predškolske dobi s različitim teškoćama $u$ razvoju. Drugu skupinu činili su dječaci normativnog razvoja iste dobi te su polaznici 20 različitih vrtića s redovnim programom diljem Republike Hrvatske. Uzorak je uključio samo mušku djecu jer je u populaciji djece s teškoćama u razvoju znatno veći postotak muške djece u odnosu na žensku djecu. Jedan je dio roditelja mjerne instrumente dobio u vrtićima, a potom su ih roditelji vraćali. Drugi dio roditelja upitnike je popunjavao u online obliku. U istraživanju su sudjelovala ukupno 193 roditelja, od čega je bilo 67 očeva i 126 majki. Ukupno je bilo 116 roditelja djece normativnog razvoja i 77 roditelja djece $s$ teškoćama u razvoju. Majki djece normativnog razvoja bilo je 85, a majki djece s teškoćama u razvoju bilo je 41 . Obuhvaćen je 31 otac djece normativnog razvoja i 36 očeva djece s teškoćama u razvoju. Prosječna je dob obiju skupina roditelja $\mathrm{M}=37,69$ godina $\mathrm{u}$ rasponu od 24 do 50 godina. Prosječno odstupanje iznosi $\mathrm{SD}=5,53$ godine. Prosječna je dob roditelja djece $\mathrm{s}$ teškoćama $\mathrm{M}=40,25(\mathrm{SD}=4,86) \mathrm{u}$ rasponu od 28 do 50 , dok je prosječna dob roditelja djece normativnog razvoja $\mathrm{M}=36(\mathrm{SD}=5,31) \mathrm{u}$ rasponu od 24 do 48 . Sociodemografske značajke roditelja koji su sudjelovali u istraživanju prikazane su u Tablici 1.

Promatrajući sociodemografske značajke dviju skupina roditelja, zaključuje se da najveći broj roditelja ima dvoje djece. Međutim postotak obitelji koji imaju dvoje djece ipak je veći kod onih koji imaju dijete normativnog razvoja $(60,34 \%) \mathrm{u}$ odnosu na one obitelji koji imaju dijete s teškoćama $(48,05 \%)$. Također može se primijetiti da obitelji koje imaju dijete $s$ teškoćama u većem postotku imaju troje, četvero, petero i sedmero djece. Nadalje zaposlenih i nezaposlenih roditelja više je u obiteljima djece normativnog razvoja, dok je više roditelja koje su na rodiljnom dopustu u obiteljima djece s teškoćama. Taj podatak ne iznenađuje jer with the potential availability of social support from family and friends.

\section{METHOD}

\section{Participants and the procedure}

Two groups of parents participated in the study. The first group consisted of parents of children of normative development and the second group of parents of children with developmental disabilities. The target group were parents of 4- and 5-year old male children. The first group consisted of boys who had an objective diagnosis of developmental difficulties. This group of boys, with various developmental difficulties, consisted of participants in one kindergarten in which various educational and rehabilitation programs are implemented for children of early and preschool age with different developmental difficulties. The second group consisted of boys of normative development of the same age who attended 20 different kindergartens with a regular program throughout the Republic of Croatia. The study focused on boys with disabilities because there is a significantly higher percentage of male children compared to female children in the population of children with disabilities.

Measuring instruments were partly distributed to parents in kindergartens who completed and returned the instruments. Other parents filled in an online form of the questionnaire. A total of 193 parents participated in the study, of whom 67 were fathers and 126 were mothers. There were a total of 116 parents of children of normative development and 77 parents of children with disabilities. There were 85 mothers of children with normative development and 41 mothers of children with disabilities; 31 were fathers of children of normative development and 36 were fathers of children with disabilities. The average age of parents was $M=$ 37.69 , ranging from 24 to 50 years. The average deviation was $S D=5.53$ years. The average age of parents of children with disabilities was $M=40.25$ $(S D=4.86)$ in the range of $28-50$ years, while the average age of parents of children with normative development was $M=36(S D=5.31)$ in the range of 24 to 48 years. Sociodemographic characteristics of the parents who participated in the research are shown in Table 1. 
Tablica 1. Sociodemografske značajke roditelja djece s teškoćama u razvoju i djece normativnog razvoja (prikaz je u postotcima) / Table 1. Sociodemographic characteristics of parents of children with disabilities and children of normative development (shown in percentages)

\begin{tabular}{|c|c|c|c|}
\hline $\begin{array}{l}\text { Sociodemographic } \\
\text { characteristics }\end{array}$ & & $\begin{array}{c}\text { Parents of children with } \\
\text { disabilities }(\%)\end{array}$ & $\begin{array}{c}\text { Parents of normative } \\
\text { development children (\%) }\end{array}$ \\
\hline Number of children in the family & \begin{tabular}{|l} 
One \\
Two \\
Three \\
Four \\
Five \\
Six \\
Seven
\end{tabular} & $\begin{array}{c}16.88 \\
48.05 \\
23.38 \\
5.19 \\
5.19 \\
0 \\
1.30\end{array}$ & $\begin{array}{c}20.69 \\
60.34 \\
17.21 \\
1.72 \\
0 \\
0 \\
0\end{array}$ \\
\hline Work status of parents & $\begin{array}{l}\text { Employed } \\
\text { Nonemployed } \\
\text { Maternity/paternity } \\
\text { leave }\end{array}$ & $\begin{array}{c}64.94 \\
7.79 \\
27.27\end{array}$ & $\begin{array}{c}79.31 \\
16.38 \\
4.31\end{array}$ \\
\hline Education level of parents & \begin{tabular}{|l} 
Primary \\
Secondary \\
Higher \\
High \\
\end{tabular} & $\begin{array}{c}2.60 \\
72.73 \\
7.79 \\
16.88 \\
\end{array}$ & $\begin{array}{c}0 \\
60.34 \\
12.93 \\
26.72 \\
\end{array}$ \\
\hline $\begin{array}{l}\text { Self-assessment of family } \\
\text { material status }\end{array}$ & $\begin{array}{l}\text { Below average } \\
\text { Average } \\
\text { Above average } \\
\text { Significantly above } \\
\text { average }\end{array}$ & $\begin{array}{c}7.79 \\
79.22 \\
10.39 \\
2.60\end{array}$ & $\begin{array}{c}3.45 \\
70.69 \\
25 \\
0.86\end{array}$ \\
\hline Marital status & \begin{tabular}{|l} 
Single \\
In a relationship \\
Extramarital union \\
Married \\
Widow/er
\end{tabular} & $\begin{array}{c}3.90 \\
1.30 \\
7.80 \\
87.01 \\
0\end{array}$ & $\begin{array}{c}1.72 \\
0.86 \\
7.76 \\
87.93 \\
1.72 \\
\end{array}$ \\
\hline Place of residence & $\begin{array}{l}\text { City } \\
\text { Town }\end{array}$ & $\begin{array}{l}57.14 \\
42.86 \\
\end{array}$ & $\begin{array}{l}70.69 \\
29.31 \\
\end{array}$ \\
\hline
\end{tabular}

vjerojatno roditelji koriste to pravo upravo zbog zdravstvenog stanja djeteta. Najveći broj roditelja u obje skupine ima srednju stručnu spremu. Višu i visoku stručnu spremu češće imaju roditelji djece normativnog razvoja. Bračni status dviju skupina roditelja vrlo je sličan. Podjednak je postotak roditelja koji su u braku ili žive u izvanbračnoj zajednici. Nešto je veći postotak roditelja koji žive sami u skupini roditelja djece s teškoćama u razvoju. Također može se primijetiti da je manje roditelja iz grada i više sa sela u skupini djece $s$ teškoćama u razvoju, iako je vrtić iz kojega dolaze djeca gradski vrtić.

\section{MJERNI INSTRUMENTI}

Skalu privrženosti kao stanja (State Adult Attachment Measure-SAAM; Gillath i sur., 2009), adaptirale su hrvatske autorice Ombla i Jurkin (2014). Skala se sastoji se od 21 tvrdnje i izvorno
Observing the sociodemographic characteristics of two groups of parents, most parents had two children. However, the percentage of families with two children was still higher among those with a child of normative development (60.34\%) compared to those with a child with disabilities (48.05\%). Also, families that had a child with disabilities had three, four, five and seven children in a higher percentage. Furthermore, there were more employed and unemployed parents in the families of children of normative development, while more parents who were on maternity/paternity leave were in families of children with disabilities. This result is not is not surprising, since it is likely that parents used this right precisely because of the child's health condition. The largest number of parents in both groups had secondary education. Higher and high education was more prevalent in the group of parents of children of normative development. The marital status of the 
je konstruirana s ciljem da pokrije cijeli raspon osjećaja i ponašanja vezanih s trenutnim stanjem privrženosti u bliskim odnosima. Podaci izvorne validacijske studije govore o trofaktorskoj strukturi SAAM-a, odnosno o tri subskale koje broje svaka po sedam tvrdnji (Sigurnost, Anksioznost i Izbjegavanje). Prilikom primjene od ispitanika se traži da izraze svoje slaganje s tvrdnjama u odnosu na to kako se trenutno osjeća procjenom na ljestvici za odgovore od sedam stupnjeva, pri čemu 1 označava "uopće se ne slažem" a 5 "u potpunosti se slažem".

Konfirmatornom faktorskom analizom izdvojena su tri faktora koja odgovaraju izvornoj verziji, a to su sigurnost, traženje blizine i izbjegavanje (autorice su preimenovale nazive subskala sukladno njihovom sadržaju). Subskala sigurnosti koja mjeri privrženost temeljenu na sigurnosti u bliskim odnosima objašnjava $18 \%$ zajedničke varijance ukupnog rezultata. Tvrdnja s najvišim zasićenjem glasi: "Kada bi nešto u ovom trenutku pošlo po zlu, osjećam da bih imao/la nekog na koga bih se mogao/la osloniti”. Traženje blizine može se najbolje definirati kao trenutna potreba za blizinom značajne osobe. Ova subskala objašnjava $16 \%$ zajedničke varijance ukupnog rezultata, a tvrdnja s najvećim zasićenjem glasi: "Trenutno mi je doista potrebno da me netko bezuvjetno voli". Subskala izbjegavanja odnosi se na izbjegavanje osoba, bliskosti i povezanosti bez obzira na osjećaj usamljenosti. Ova subskala objašnjava 13\% zajedničke varijance ukupnog rezultata. Tvrdnja na subskali izbjegavanja koja ima najveće zasićenje glasi: "Plaši me ideja da bi netko želio postati preblizak sa mnom". U konačnici sve 3 subskale objašnjavaju $67 \%$ zajedničke varijance ukupnog rezultata. Tako dobivene subskale imaju zadovoljavajuću pouzdanost. Subskala sigurnosti ima pouzdanost Cronbach alfa $=0,83$, subskala blizine ima pouzdanost Cronbach alfa $=0,80$, a subskala izbjegavanja Cronbach alfa $=0,71$. Može se zaključiti kako SAAM pokazuje zadovoljavajuće metrijske karakteristike te dobiveni rezultati govore u prilog tome da privrženost kao stanje odgovara opisu strategije privrženosti kao stabilne osobine zasnovane na osjećaju sigurnosti.

Skala kvalitete obiteljskog funkcioniranja (The Self-Report Family Inventory: Version II- two groups of parents was very similar. There was an equal percentage of parents who were married or living in an extramarital union. There was a slightly higher percentage of parents living alone in the group of parents of children with disabilities. Also, fewer parents were from a city and more from a town in the group of children with disabilities, although the kindergarten the children attended is a city kindergarten.

\section{MEASURING INSTRUMENTS}

The State Adult Attachment Measure (SAAM; Gillath et al., 2009) has been adapted by Croatian authors Ombla and Jurkin (2014). The scale consists of 21 statements and was originally constructed with the aim of covering the whole range of feelings and behaviours related to the current state of attachment in close relationships. The data from the original validation study showed a three-factor structure of SAAM, that is, three subscales that count seven items each (Safety, Anxiety, and Avoidance). When applying the measure, respondents are asked to express their agreement with the statements regarding how they currently feel on a seven-point rating scale, with 1 indicating "strongly disagree" and 5 "strongly agree".

Confirmatory factor analysis identified the three factors corresponding to the original version: security, proximity seeking, and avoidance (the authors renamed the subscale names according to their content). The security subscale, which measures attachment based on security in close relationships, explained $18 \%$ of the total variance of the total score. The item with the highest saturation was: "If something went wrong at this point, I feel like I would have someone to rely on." Proximity seeking can best be defined as the immediate need for closeness of a significant person. This subscale explained $16 \%$ of the total variance of the total score, and the item with the highest saturation was: "Right now, I really need someone to love me unconditionally." The avoidance subscale refers to the avoidance of persons, closeness and connection, regardless of feelings of loneliness. This subscale explained $13 \%$ of the total variance of the total score. The item on the avoidance subscale with the highest saturation was: "I'm scared of the idea that someone might want to get too close to me." Ultimately, all 3 subscales explained $67 \%$ of the total variance of the total score. The obtained 
SFI; Beavers i Hampson, 1990) ispituje percepciju kvalitete interakcija između članova obitelji i kvalitete funkcioniranja obitelji u cjelini. Skalu su adaptirale hrvatske autorice Śimunić i Gregov (2010). Sastoji se od 35 tvrdnji. Ispitanik odgovara tako da izražava stupanj slaganja s pojedinom tvrdnjom na skali od pet stupnjeva (od 1 "uopće se ne slažem" do 5 "u potpunosti se slažem"). Skala sadrži 4 subskale: zajedništvo, skladnost, konflikt i toleranciju. Ukupni rezultat po subskalama definira se kao prosječna vrijednost (raspon od 1 do 5) gdje veći rezultat odražava veći stupanj skladnosti, tolerancije i zajedništva, a niži rezultat ukazuje na viši stupanj konflikata unutar obitelji.

Zbog niske korelacije s ukupnim rezultatom tvrdnje $6,11,16,23$ u ovom su istraživanju izostavljene iz daljnje analize. Autorice skale sugeriraju mogućnost formiranja ukupnog rezultata koji bi predstavljaju ukupnu kvalitetu obiteljskog funkcioniranja. Stoga je provedena konfirmatorna faktorska analiza koja ukazuje na zadovoljavajuću faktorsku soluciju koja objašnjava 33,9\% zajedničke varijance. Pouzdanost ovako dobivenog mjernog instrumenta iznosi Cronbach alfa $=0,95$. Tvrdnja s najvišim zasićenjem na Skali kvalitete obiteljskog funkcioniranja glasi: "Mi kao obitelj smo dobri i fleksibilni u rješavanju problema".

Skalu socijalne podrške (MacDonald, 1998) adaptirala je hrvatska autorica Ivanov (2010). Skala opisuje percepciju primljene socijalne podrške od članova obitelji i prijatelja, a odnosi se ne samo na potencijalno raspoloživu već i na socijalnu podršku koja se upravo koristi. Ona također uključuje zadovoljstvo odnosno pozitivnu evaluaciju socijalne podrške. Originalna skala ima 14 subskala te se sastoji od 56 tvrdnji od kojih se 28 tvrdnji odnosi na socijalnu podršku obitelji, a 28 na socijalnu podršku prijatelja. Svaka od tih dviju subskala sadrži po četiri tipa socijalne podrške: emocionalnu podršku, instrumentalnu podršku, informacijsku podršku i podršku samopoštovanju. Autorica skale navodi više mogućih načina upotrebe skale, ovisno o ciljevima istraživanja ili potrebama prakse. Ispitanici označavaju slaganje sa svakom pojedinom tvrdnjom na skali od 5 stupnjeva, pri čemu se zaokruživanjem broja 1 "uopće ne slažu", a zaokruživanjem broja 5 "u potpunosti slažu" s navedenom tvrdnjom. Ukupan rezultat formira se kao linearna kombinacija odgo- subscales had satisfactory reliability. The safety subscale had a Cronbach alpha reliability of .83; the proximity subscale, .80 ; and the avoidance subscale, .71. It can be concluded that SAAM exhibits satisfactory metric characteristics, and the results show that attachment as a condition corresponds to the description of attachment strategy as a stable trait based on a sense of security.

The Family Self-Report Quality Inventory Scale (Version II - SFI; Beavers and Hampson, 1990) examines the perception of the quality of interactions between family members and the quality of family functioning as a whole. The scale was adapted by Croatian authors Šimunić and Gregov (2010). It consists of 35 items. The respondents express their degree of agreement with each statement on a five-point scale (from 1 - strongly disagree, to 5 - strongly agree). The scale contains 4 subscales: togetherness, harmony, conflict and tolerance. The total subscale scores are defined as the average values on the corresponding items (range, 1 to 5) where a higher score reflects a greater degree of harmony, tolerance and togetherness, and a lower score indicates a higher degree of intra-family conflict.

Due to low factor saturations, items $6,11,16$, and 23 were omitted. The authors of the scale suggest the possibility of forming an overall result that would represent the overall quality of family functioning. Therefore, a confirmatory factor analysis was performed, which indicated a satisfactory factor solution explaining $33.9 \%$ of the common variance. The reliability of the measuring instrument thus obtained was Cronbach alpha $=.95$. The item with the highest saturation on the Scale of Quality of Family Functioning was: "We as a family are good and flexible in solving problems."

Social Support Scale (MacDonald, 1998). The scale was adapted by the Croatian author Ivanov (2010). The scale describes the perception of received social support from family members and friends, and refers not only to the potentially available, but also to the currently used social support. It also includes satisfaction or the positive evaluation of social support. The original scale has 14 subscales and consists of 56 statements, 28 of which relate to family social support and 28 to social support from friends. Each of these two 
vora na svim tvrdnjama skale, odnosno subskale, vodeći računa o tvrdnjama koje se obrnuto boduju.

S obzirom na sugestije autora provedena je konfirmatorna faktorska analiza kako bi se potvrdila dvofaktorska struktura koja uključuje socijalnu podršku obitelji (tvrdnja s najvišim zasićenjem glasi: "Moja obitelj pokazuje da im je stalo do mene") i socijalnu podršku prijatelja (tvrdnja s najvišim zasićenjem glasi: "Kada trebam savjet, mogu se obratiti svojim prijateljima”). Subskala podrška obitelji objašnjava $45 \%$ zajedničke varijance ukupnog rezultata, a pouzdanost iznosi Cronbach alfa $=0,95$. Subskala podrška prijatelja objašnjava $52 \%$ zajedničke varijance ukupnog rezultata i Cronbach alfa $=0,96$. Skala socijalne podrške mjeri primljenu i dostupnu socijalnu podršku od članova obitelji i od prijatelja. Viši rezultat ne ukazuje na veću socijalnu podršku.

\section{REZULTATI}

S obzirom da distribucije rezultata na svim skalama odstupaju od normalne (Tablica 2), prilikom obrade koristili smo se neparametrijskim statističkim postupcima. Prvi korak u obradi rezultata činila je deskriptivna statistika za mjerene varijable posebno za roditelje djece s teškoćama u razvoju i za roditelje djece normativnog razvoja.

Rezultati govore o relativno velikoj sigurnosti kad je u pitanju privrženost u bliskim odnosima. Roditelji izvješćuju o relativno visokoj sigurnosti i niskoj razini izbjegavanja u bliskom odnosu kao i o visokoj razini traženja blizine i emocionalne potpore u bliskim odnosima. Kad je riječ o kvaliteti obiteljskog funkcioniranja ona je općenito prilično visoka. Za obiteljsku podršku kao i za podršku prijatelja rezultati su pokazali da je prosječna vrijednost blizu maksimalne vrijednosti na skali, odnosno vrlo je visoka. Općenito su razine socijalne podrške u obje domene prilično visoke.

\section{Usporedba obrasca privrženosti između roditelja djece s teškoćama u razvoju i roditelja djece normativnog razvoja}

Prvi istraživački problem bio je utvrditi postoje li razlike u bliskim odnosima roditelja djece normativnog razvoja i roditelja djece s teškoćama u subscales contains four types of social support: emotional support, instrumental support, information support, and self-esteem support. The author of the scale outlines several possible ways to use the scale, depending on the research goals or needs of practice. Respondents indicate their agreement with each statement on a 5-point scale, with 1 referring to complete disagreement and 5 to complete agreement with the statement. The total score is formed as a linear combination of responses on all the statements of the scale or subscales, while taking into account the statements that are reversed.

In the light of the author's suggestions, a confirmatory factor analysis was performed to confirm a two-factor structure that included social support for the family (the item with the highest saturation was: "My family shows that they care about me") and social support from friends (the item with the highest saturation was: "When I need advice, I can turn to my friends"). The family support subscale explained $45 \%$ of the total variance of the total score, and the reliability was Cronbach alpha $=.95$. The Friends Social Support subscale explained $52 \%$ of the total variance of the total score and Cronbach alpha $=.96$. The Social Support Scale measures the social support received and available from family members and friends. A higher score indicates greater social support.

\section{RESULTS}

Because the distributions of the results on all scales deviated from normal (Table 2), we used non-parametric statistical procedures when analysing them. The first step of analysis was the computation of descriptive statistics for the measured variables, separately for parents of children with disabilities and parents of children of normative development.

The results indicated a relatively secure attachment in close relationships. Parents showed relatively high security and low levels of avoidance in a close relationship, as well as a high demand for closeness and emotional support in close relationships. When it came to the quality of family functioning, it was generally quite high. For support from both family and friends, the results showed that the average value was close to the maximum, or very high. In general, the levels of social support in both domains were quite high. 
Mira Klarin, Višnja Čirjak, Slavica Šimić Šašić: Usporedba percepcije bliskih odnosa roditelja djece s teškoćama u razvoju i roditelja djece...

Tablica 2. Rezultati deskriptivne statistike zasebno za dvije skupine roditelja / Table 2. Results of descriptive statistics analyses for the two groups of parents

\begin{tabular}{|l|c|c|c|c|c|c|c|c|c|c|}
\hline & \multicolumn{4}{|c|}{$\begin{array}{c}\text { Parents of children with developmental } \\
\text { disabilities (N= 77) }\end{array}$} & \multicolumn{5}{c|}{ Parents of children of normative development } \\
(N=116)
\end{tabular}

Tablica 3. Rezultati testiranja razlika u obrascu privrženosti između roditelja djece s teškoćama i roditelja djece normativnog razvoja / Table 3. The results of testing the differences in attachment patterns between parents of children with disabilities and parents of children of normative development

\begin{tabular}{lccccccc}
\hline & $\boldsymbol{N}_{\boldsymbol{1}^{*}}$ & $\boldsymbol{N}_{2^{\star *}}$ & Group 1 sum of ranks & Group 2 sum of ranks & $\boldsymbol{U}$ & $\boldsymbol{Z}$ & $\boldsymbol{p}$ \\
\hline Security & 77 & 116 & 6443 & 12278 & 3444 & 2.70 & .007 \\
Proximity-seeking & 77 & 116 & 6974 & 11747 & 3971 & 1.30 & .192 \\
Avoidance & 77 & 116 & 7645.50 & 11075.50 & 4289.50 & 0.46 & .642 \\
\hline
\end{tabular}

$* N_{l}$ - parents of children with disabilities;

$* * N_{2}$ - parents of children of normative development

razvoju. U Tablici 3 prikazani su rezultati testiranja razlike Mann-Whitneyevim U testom.

Rezultati su pokazali da roditelji djece s teškoćama u razvoju u značajno manjoj mjeri temelje privrženost u bliskim odnosima na traženju sigurnosti, odnosno njihov osjećaj sigurnosti u bliskim odnosima značajno je slabiji u odnosu na osjećaj sigurnosti koji imaju roditelji djece normativnog razvoja. U ostala dva aspekta privrženosti nema statistički značajne razlike.

\section{Testiranje razlike u obrascu privrženosti kod očeva u odnosu na obrazac privrženosti kod majki}

Da bi se utvrdilo postoje li razlike u trima aspektima privrženosti kod očeva u odnosu na majke, provedeno je testiranje neparametrijskim Mann-Whitneyevim U testom (Tablica 4).

Rezultati su pokazali kako je u grupi roditelja koji imaju djecu s teškoćama u razvoju značajno jače izraženo traženja blizine kod majki nego kod očeva $(U=526, Z=2.16, p=0.03)$. U drugim aspektima privrženosti u bliskim odnosima nema statistički značajne razlike s obzirom na spol. Također rezultati upućuju na zaključak da nema statistički značajne razlike $u$ aspektima privrženosti

\section{Comparison of attachment patterns between parents of children with disabilities and parents of children of normative development}

The first research problem was to determine whether there were statistically significant differences in the close relationships between parents of children of normative development and parents of children with disabilities. Table 3 shows the results of difference testing expressed by the Mann-Whitney U test.

The results showed that parents of children with disabilities based their attachment in close relationships on seeking security/safety to a lower degree, that is, their sense of security in close relationships was significantly lower than the sense of security that parents of children of normative development had. There were no statistically significant differences in the other two aspects.

\section{Testing the difference in the attachment patterns in fathers versus the attachment patterns in mothers}

To determine whether there were differences in the various aspects of attachment in fathers with respect to the pattern of attachment in mothers, a non-parametric Mann-Whitney U test was performed (Table 4). 
Tablica 4. Rezultati testiranja razlika u obrascima privrženosti s obzirom na spol za dvije skupine roditelja / Table 4. The results of testing gender differences in attachment patterns for the two groups of parents

\begin{tabular}{|l|c|c|c|c|c|c|c|}
\hline & $\boldsymbol{N}_{\boldsymbol{1}^{*}}$ & $\boldsymbol{N}_{2^{* *}}$ & $\begin{array}{c}\text { Group 1 sum of } \\
\text { ranks }\end{array}$ & $\begin{array}{c}\text { Group 2 sum of } \\
\text { ranks }\end{array}$ & $\boldsymbol{U}$ & $\boldsymbol{Z}$ & $\boldsymbol{P}$ \\
\hline \\
\hline PARENTS OF CHILDREN WITH DISABILITIES \\
\hline Security & 36 & 41 & 1690 & 1313 & 647 & 0.92 & .924 \\
\hline Proximity-seeking & 36 & 41 & 1811 & 1192 & 526 & 2.16 & .031 \\
\hline Avoidance & 36 & 41 & 1494.50 & 1508.50 & 633.50 & 1.06 & .289 \\
\hline
\end{tabular}

PARENTS OF CHILDREN OF NORMATIVE DEVELOPMENT

\begin{tabular}{|c|c|c|c|c|c|c|c|}
\hline Security & 36 & 41 & 5131.50 & 1654.50 & 1158.50 & 0.99 & .323 \\
\hline Proximity-seeking & 36 & 41 & 4996 & 1790 & 1294 & 0.14 & .886 \\
\hline Avoidance & 36 & 41 & 5140.50 & 1654.50 & 1149.50 & 1.05 & .296 \\
\hline
\end{tabular}

$* N_{1}$ - women

$* * N_{2}-$ men

Tablica 5. Rezultati testiranja razlike u kvaliteti obiteljskog funkcioniranja roditelja djece s teškoćama i djece normativnog razvoja / Table 5. Results of testing the difference in the quality of family functioning in parents of children of normative development compared to parents of children with disabilities

\begin{tabular}{|l|c|c|c|c|c|c|c|}
\hline & $\boldsymbol{N}_{1^{*}}$ & $\boldsymbol{N}_{2^{* *}}$ & $\begin{array}{c}\text { Group 1 sum of } \\
\text { ranks }\end{array}$ & $\begin{array}{c}\text { Group 2 sum of } \\
\text { ranks }\end{array}$ & $\boldsymbol{U}$ & $\boldsymbol{Z}$ & $\boldsymbol{P}$ \\
\hline Quality of family functioning & 77 & 116 & 6784 & 11937 & 3781 & 1.80 & .072 \\
\hline
\end{tabular}

$* N_{1}$ - parents of children with disabilities

$* * N_{2}$ - parents of children of normative development

u bliskim odnosima očeva i majki djece normativnog razvoja.

\section{Rezultati testiranja razlike u kvaliteti obiteljskog funkcioniranja u obiteljima djece normativnog razvoja u odnosu na obitelji djece s teškoćama u razvoju}

Treći istraživački problem bio je provjeriti postoji li statistički značajna razlika u kvaliteti obiteljskog funkcioniranja roditelja djece normativnog razvoja u odnosu na roditelje djece s teškoćama $u$ razvoju.

Rezultati upućuju na blago sniženu kvalitetu obiteljskog funkcioniranja roditelja djece s teškoćama u razvoju, ali ona nije statistički značajna.

\section{Rezultati testiranja razlike u kvaliteti obiteljskog funkcioniranja s obzirom na spol za dvije skupine roditelja}

U procjeni kvalitete obiteljskog funkcioniranja nema statistički značajne razlike između majki i očeva $(\mathrm{U}=3667, \mathrm{z}=-1,34, \mathrm{p}=0,179)$. Majke $\mathrm{i}$
The results showed that there was significantly more proximity-seeking by mothers than by fathers in the group of parents with children with disabilities $(U=526, Z=2.16, p=.03)$. In other aspects of attachment in close relationships, there was no statistically significant difference with respect to gender. Also, the results suggest that there was no statistically significant difference in attachment aspects in the close relationships of fathers and mothers of children of normative development.

Testing the differences in the quality of family functioning in families of children of normative development compared to families of children with disabilities

The third research question was to check whether there was a statistically significant difference in the quality of family functioning in the families of children of normative development in comparison to the families of children with disabilities (Table 5).

The results indicate a slightly reduced quality of family functioning for parents of children with disabilities, but it was not statistically significant. 
Mira Klarin, Višnja Čirjak, Slavica Šimić Šašić: Usporedba percepcije bliskih odnosa roditelja djece s teškoćama u razvoju i roditelja djece...

Tablica 6. Rezultati testiranja razlika u socijalnoj podršci roditelja djece s teškoćama i djece normativnog razvoja / Table 6. Results of testing the difference in social support assessed by parents of children with disabilities and parents of children with normative development

\begin{tabular}{|l|c|c|c|c|c|c|c|}
\hline & $\boldsymbol{N}_{\mathbf{I}^{*}}$ & $\boldsymbol{N}_{2^{* *}}$ & Group 1 sum of ranks & Group 2 sum of ranks & $\boldsymbol{U}$ & $\boldsymbol{Z}$ & $\boldsymbol{p}$ \\
\hline Family support & 77 & 116 & 6734 & 3731 & 3731 & 1.93 & .053 \\
\hline Support from friends & 77 & 116 & 6487.50 & 3484.50 & 3484.50 & 2.58 & .009 \\
\hline
\end{tabular}

$* N_{1}$ - parents of children with disabilities

$* * N_{2}$ - parents of children of normative development

očevi podjednako procjenjuju obiteljsko funkcioniranje.

\section{Rezultati testiranja razlike u socijalnoj podršci između obitelji djece s teškoćama u razvoju i obitelji djece normativnog razvoja}

Sljedeći problem bio je utvrditi postoji li razlika u socijalnoj podršci članova obitelji i prijatelja s obzirom na to imaju li obitelji djecu s teškoćama ili ne. Rezultati su prikazani u Tablici 6 .

Rezultat pokazuje da roditelji djece s teškoćama doživljavaju rubno manju obiteljsku (razlika je na granici značajnosti) i značajno manju podršku prijatelja.

\section{Rezultati testiranja razlike u socijalnoj podršci s obzirom na spol za dvije skupine roditelja}

Uspoređujući procjene socijalne podrške obitelji majki i očeva, možemo zaključiti da ne postoji statistički značajna razlika $(\mathrm{U}=3556, \mathrm{z}=1,80$, $\mathrm{p}=0,072)$. Za razliku od procjene socijalne podrške obitelji, majke i očevi značajno se razlikuju u procjeni podrške koju dobivaju od prijatelja (Tablica 7). Pritom majke izvješćuju o većoj podršci (suma rangova očeva $=5399,500$, suma rangova majki $=13321,500, \mathrm{U}=3121,5, \mathrm{z}=-2,974, \mathrm{p}=0,003)$.

\section{RASPRAVA}

Cilj je ovog istraživanja bio ispitati obrasce privrženosti u bliskim odnosima, kvalitetu obiteljskog funkcioniranja te razinu procijenjene socijalne podrške obitelji i prijatelja kod roditelja djece s teškoćama u razvoju u usporedbi s roditeljima djece normativnog razvoja. Vidljivo je da roditelji djece s teškoćama u razvoju, kao i roditelji djece normativnog razvoja, manifestiraju relativno visoke vrijednosti na dimenzijama sigurnosti i traženja blizine.
Testing the differences in the quality of family functioning with respect to gender for the two groups of parents

There was no statistically significant difference between mothers and fathers in the assessment of the quality of family functioning $(U=3667, z=$ $-1.34, p=0.179)$. Mothers and fathers assessed family functioning similarly.

Testing the difference in social support between families of children with disabilities and families of children with normative development

Another problem was to determine whether there was a difference in social support from family members and friends with regard to whether or not they had families with children with disabilities or not. The results are presented in Table 6 .

The result shows that parents of children with disabilities experienced marginally less family support (the difference was on the verge of significance) and significantly less support from friends.

\section{Testing the difference in social support with regard to gender for the two groups of parents}

Comparing the estimates of family social support of mothers and fathers, we can conclude that there was no statistically significant difference ( $U$ $=3556, z=1.80, p=0.072)$. In contrast to the assessment of family social support, mothers and fathers differed significantly in the assessment of the support they received from friends (Table 7).

Thus, mothers reported higher support (Sum of ranks of fathers $=5399,500$, Sum of ranks of mothers $=13321,500, U=3121.5, z=-2.974, p$ $=0.003)$. 
Tablica 7. Rezultati testiranja razlika u socijalnoj podršci prijatelja za dvije skupine roditelja / Table 7. Results of testing differences in social support of friends for two groups of parents

\begin{tabular}{|l|c|c|c|c|c|}
\hline & Fathers' sum of ranks & Mothers' sum of ranks & $\boldsymbol{U}$ & $\boldsymbol{Z}$ & $\boldsymbol{p}$ \\
\hline Social support from friends & 1461.5 & 5324.5 & 965.5 & 2.20 & .028 \\
\hline
\end{tabular}

Također visoko procjenjuju kvalitetu obiteljskog funkcioniranja, kao i obiteljsku podršku i podršku prijatelja. Na dimenziji izbjegavanja obje skupine roditelja pokazuju niže rezultate. Stoga bismo mogli zaključiti da roditelji koji su sudjelovali u ovom istraživanju imaju pozitivan stil privrženosti u bliskim odnosima koji je obilježen visokim stupnjem sigurnosti i potrebom za interpersonalnom bliskošću te niskim stupnjem izbjegavanja. Sukladno tome zadovoljni su kvalitetom braka kao i primljenom podrškom obitelji i prijatelja.

Prvi problem u istraživanju bio je utvrditi postoje li razlike u obrascima privrženosti u bliskim odnosima između roditelja koji imaju dijete $\mathrm{s}$ teškoćama i roditelja djece normativnog razvoja. Koliko je nama poznato, kod nas istraživanja privrženosti u bliskim odnosima u kontekstu ove teme nisu provođena. Pod bliskim odnosima podrazumijevaju se odnosi s bliskom osobom koja može biti partner, ali može biti i neka druga osoba na koju se roditelj može osloniti i od nje dobiti podršku. No prema rezultatima istraživanja ipak je to najčešće partner/ica (Leutari Oršulić, 2015). S obzirom na to da je ova varijabla nova u istraživanjima percepcije bliskih odnosa u obiteljima koje imaju dijete s teškoćama i obiteljima koje imaju dijete normativnog razvoja i s pretpostavkom kako istraživanja ukazuju da je bliska osoba najčešće partner, dobivene rezultate usporediti ćemo u kontekstu partnerskih odnosa.

Mnogim roditeljima djece s teškoćama u razvoju teško je prepoznati odgovarajući trenutak kada odložiti djetetove potrebe te se više posvetiti odnosima s bliskim osobama. Takav odnos u većini će slučajeva dovesti do konflikata jer su partneri preplavljeni krivnjom u preoblikovanju bračnih uloga kako bi zadovoljili zahtjeve skrbi za dijete. Rezultati dobiveni ovim istraživanjem pokazali su da se roditelji djece s teškoćama u razvoju osjećaju manje sigurni u blizini bliskih osoba, osjećaju da imaju manji oslonac u drugima i svoj odnos s drugima procjenjuju manje pouzdanim, bliskim i povjerljivim u usporedbi s roditeljima djece norma-

\section{DISCUSSION}

The aim of this study was to examine patterns of attachment in close relationships, the quality of family functioning, and the level of estimated social support from family and friends in parents of children with disabilities compared with parents of children of normative development. It is evident that parents of children with disabilities, as well as parents of children of normative development, exhibit relatively high values on the dimensions of safety and proximity-seeking. They also give high values when assessing the quality of family functioning as well as support from family and friends. On the avoidance dimension, both groups of parents achieved lower scores. Therefore, we could conclude that the parents who participated in this study have a positive attachment style characterised by a high degree of security, a need for interpersonal closeness and a low level of avoidance. Accordingly, they are satisfied with the quality of their marriage as well as with the support received from family and friends.

The first problem in the study was to determine if there were differences in attachment patterns between parents with a disabled child and parents of children of normative development. As far as we know, research on attachment in close relationships in the context of this topic has not been conducted in Croatia. Close relationships are relationships with a close person who can be a partner or another person on whom the parent can rely and from whom the parent can receive support. However, according to the results of research, it is most often a partner (Leutari Oršulić, 2015). This variable is new in studies of the perception of close relationships in families with a child with disabilities and families with a child of normative development. Assuming, as research indicates, that a close person is most often a partner, we will compare the results in the context of partnerships.

Many parents of children with disabilities find it difficult to identify the right time to put their child's needs aside and to become more involved in relationships with significant others. In most cases, such a relationship will lead to conflict as partners are over- 
tivnog razvoja. Drugim riječima mogli bismo reći da se roditelji koji imaju djecu s teškoćama osjećaju nesigurnima i bliske odnose procjenjuju manje podražavajućima u odnosu na skupinu roditelja koji nemaju dijete s teškoćama. Ovakav rezultat nije neočekivan, naime možemo pretpostaviti da je sigurnost kao aspekt privrženosti kod ovih obitelji najviše narušena upravo zbog činjenice da imaju dijete s teškoćom. Martinac Dorčić i Ljubešić (2008) temeljem rezultata istraživanja govore o slabijoj kvaliteti braka, obiteljskoj kohezivnosti i prilagodljivosti roditelja koji imaju dijete s teškoćama. Rezultati istraživanja u ovom području ističu $\mathrm{s}$ jedne strane da se roditelji koji imaju dijete $\mathrm{s}$ teškoćom u razvoju mogu osjetiti puno povezanijima i to može dodatno učvrstiti njihovu bračnu vezu is druge strane da je roditeljima dijete s teškoćom $u$ razvoju velik teret za njihovu bračnu vezu (Baker i sur., 2005). U skladu s tim studije su pokazale da su neki roditelji osnažili svoj bračni odnos dok je za druge roditelje dijete s teškoćom u razvoju imalo negativan učinak na njihov bračni odnos (Heiman, 2002.). Dakle za neke je roditeljstvo djetetu s teškoćom u razvoju bila prilika da ojačaju svoju bračnu vezu dok je za druge roditeljstvo djetetu s teškoćom bila teškoća koja je oslabila njihovu bračnu vezu. Neka pak istraživanja ukazuju na zaključak da se kvaliteta partnerskih odnosa ne razlikuje s obzirom na to ima li obitelj dijete s teškoćama (Leutar i Starčić, 2007) te da mediji prenose takvu krivu sliku negativne povezanosti kvalitete partnerskog odnosa i zdravstvenog statusa djeteta (Hartley i sur., 2011). Rezultati našeg istraživanja pokazuju da roditelji djece s teškoćama u razvoju u manjoj mjeri u svojim bliskim odnosima pronalaze sigurnost, pouzdanje i povjerenje što vodi zaključku o povećanoj motivaciji za razvoj bliskih odnosa u toj specifičnoj situaciji. Stres kod majki i očeva, koji je povezan s roditeljstvom, pojavljuje se čim se dijete rodi bez obzira na to je li dijete normativnog razvoja ili ima razvojnu teškoću (Bleacher i sur., 1997). Socijalna podrška, osobito partnera, svakako je značajna komponenta roditeljstva, prije svega u obiteljima s djecom s teškoćama u razvoju (Leutar i Oršulić, 2015).

Drugo pitanje bilo je utvrditi je li obrazac privrženosti različit za majke u odnosu na očeve u obiteljima djece normativnog razvoja kao i u obiteljima whelmed with guilt in reshaping marital roles to meet the demands of child care. The results of this study showed that parents of children with disabilities feel less secure in the vicinity of close persons, feel less reliant on others, and evaluate their relationship with others as less trustworthy, close and trusting than parents of children of normative development. In other words, it could be said that parents with children with disabilities feel insecure and close relationships are perceived as less stimulating compared to the group of parents who do not have a child with disabilities. This is not an unexpected result, as we can assume that security as an attachment aspect in these families is most severely affected by the fact that they have a child with a disability. The results of the research of Martinac Dorčić and Ljubešić (2008) show a lower quality of marriage, family cohesiveness and adaptability of parents with a child with disabilities. Research findings in this area highlight, on the one hand, that parents with a child with developmental disabilities may feel much more connected, and this may further strengthen their marital relationship and, on the other hand, that parents of a child with developmental disabilities have a great burden on their marital relationship (Baker et al., 2005). Accordingly, studies have shown that some parents strengthened their marital relationship, while for other parents, a child with disabilities had a negative effect on their marital relationship (Heiman, 2002). Thus, for some parents, parenting a child with a developmental disability is an opportunity to strengthen their marital relationship, while for other parents, parenting a child with a disability is a difficulty that weakens their marital relationship. Some studies, however, suggest that the quality of partnerships does not differ with regard to whether the family has or does not have a child with disabilities (Leutar \& Starčić, 2007). The results of our study show that parents of children with disabilities perceive lower extents of security, confidence and trust in their close relationships, which leads to the conclusion that there is an increased motivation to develop close relationships in this specific situation. Maternal and paternal stress, which is associated with parenting, occurs as soon as the child is born, whether the child is of normative development or has a developmental disability (Bleacher et al., 1997). Social support, especially from the partner, is certainly a significant component of parenting, especially in families with children with disabilities (Leutar \& Oršulić, 2015). 
djece s teškoćama u razvoju. Pretpostavili smo da će postojati razlike u obrascima privrženosti između očeva i majki s obzirom na to da majke najčešće preuzimaju najveću brigu o djetetu. Rezultati upućuju na zaključak da u obiteljima u kojima je dijete s teškoćama, očevi manje traže blizinu, nego što je to slučaj kod majki. Za roditelje koji nemaju dijete s teškoćama razlika nije statistički značajna. Majke koje imaju dijete s teškoćama ističu veću potrebu za emocionalnom blizinom, ljubavlju, dijeljenjem osjećaja i razgovorom u odnosu na očeve iz ovih obitelji. Majke najčešće ne osjećaju da su očevi dovoljno uključeni u brigu o djeci, a brinuti o djetetu s teškoćom zasigurno je teže od brige za dijete normativnog razvoja te bi se teret brige o djetetu trebao ravnomjernije podijeliti s očevima. Razgovor o problemima koji tište obitelj djeteta s teškoćama kao i razmjena iskustava i osjećaja majkama bi sigurno olakšali brigu o djetetu. Također veća bliskost među supružnicima sigurno bi pridonijela većoj uključenosti i pomoći očeva u brizi za dijete pa bi se i majke osjećale bolje. Podjela poslova vezanih uz skrb za dijete s teškoćama temelji se na prepoznavanju mogućnosti svakog od partnera te je izuzetno važno razgovorom utvrditi ono što partner osjeća.

Treće istraživačko pitanje bilo je usporediti i ispitati je li kvaliteta obiteljskog funkcioniranja različita u obiteljima djece normativnog razvoja u odnosu na obitelji djece s teškoćama u razvoju. Pretpostavili smo kako razvojne teškoće kod djeteta utječu na obiteljsko funkcioniranje te tako predstavljaju izvor stresa za obitelj s djetetom koje ima teškoće. Dobiveni rezultati pokazuju da postoji blago snižena kvaliteta obiteljskog funkcioniranja za roditelje djece s teškoćama, ali razlika nije statistički značajna. Ovakav rezultat razlikuje se od Whitingove studije (2014) koja je pokazala izrazito lošu kvalitetu obiteljskog funkcioniranja u obiteljima djece s teškoćama. Zbog dodatne njege koja je potrebna za dijete s teškoćama roditelji nemaju dovoljno vremena za druge aktivnosti, što onda utječe na njihov društveni život i druženje s rođacima i prijateljima (Whiting, 2014). Isto tako briga o djetetu s teškoćama predstavlja i izvor financijskog stresa za roditelje zbog troškova dodatne njege, a potrebno im je i fleksibilno radno vrijeme što rezultira propuštenim poslovnim prilikama (Whiting,
The second problem was to determine whether the attachment pattern was different for mothers compared to fathers in families of children of normative development as well as in families of children with disabilities. We hypothesised that there would be differences in attachment patterns between fathers and mothers given that mothers most often provide the greatest care for the child. The results suggest that, in families with a child with disabilities, fathers are less likely to seek proximity than mothers. For parents who do not have a child with disabilities, the difference is not statistically significant. Mothers with a child with disabilities emphasise a greater need for emotional closeness, love, sharing feelings and conversation than fathers from these families. Most often, mothers do not feel that fathers are sufficiently involved in childcare, and caring for a disabled child is certainly more difficult than caring for a child of normative development, so the burden of caring for a child should be more evenly shared with fathers. Talking about problems that plague the family of a disabled child and sharing experiences and feelings would certainly make it easier for mothers to care for their child. Also, greater closeness between spouses would certainly contribute to greater involvement and assistance of fathers in caring for the child, so mothers would feel better. The division of affairs related to the care of a child with disabilities is based on recognising the capabilities of each partner and it is extremely important to determine what the partner is feeling through conversation.

The third research question was to examine whether the quality of family functioning was different in families of children with normative development compared to families of children with disabilities. We hypothesised that developmental disabilities in a child affect family functioning and thus represent a source of stress for a family with a child with disabilities. The results show that there is a slight decrease in the quality of family functioning for parents of children with disabilities, but the difference is not statistically significant. This result differs from the study conducted by Whiting (2014), which showed a markedly poor quality of family functioning in families of children with disabilities. Due to the extra care needed for a disabled child, parents do not have enough time for other activities, which then affects their social life and socialising with relatives and friends (Whiting, 2014). Also, caring for a child with disabilities is a source of financial stress 
2014). Roditeljima je između ostalog problem i to što nisu samo majke i očevi svojoj djeci nego postaju i fizioterapeuti i medicinske sestre te imaju puno uloga za razliku od roditelja djece normativnog razvoja (Whiting, 2014). Isti autor zaključuje da izazovi s kojima se suočavaju roditelji djece s teškoćama rezultiraju negativnim posljedicama za njihovo fizičko i mentalno zdravlje te stoga pridonose značajno nižoj kvaliteti obiteljskog funkcioniranja. Rezultati istraživanja Milić Babić (2012) ukazuju na zaključak da roditelji djece s teškoćama koji procjenjuju visoko roditeljski stres ujedno i obiteljsku kohezivnost, kao indikator obiteljskog funkcioniranja, procjenjuju nižom. S druge strane neki autori zaključuju da je kvaliteta obiteljskog funkcioniranja u obiteljima djece s teškoćama $\mathrm{u}$ razvoju jednaka kvaliteti obiteljskog funkcioniranja u obiteljima djece normativnog razvoja ili čak može biti i veća (Sobsey, 2004) na što ukazuju i naši rezultati. Razloge ovih razlika u dobivenim rezultatima možemo potražiti u činjenici da su dobiveni u različitim društvenim uređenjima. Naime istraživanje koje je proveo Whiting (2014) provedeno je u Sjedinjenim Američkim Državama. Sustav socijalne podrške u SAD-u bitno je slabiji nego što je u Republici Hrvatskoj. Prema Zakonu o rodiljnim i roditeljskim potporama $\mathrm{RH}$ roditelju djeteta s teškoćama u razvoju omogućeno je da nakon isteka prava na rodiljni dopust ima pravo na dopust za njegu djeteta do navršene 8. godine djetetova života. Također prema ovom Zakonu jedan od roditelja ima pravo na rad na pola radnog vremena, također i nakon navršene 8 . godine djetetova života, odnosno sve dok ta potreba traje, a na temelju nalaza i mišljenja Zavoda za vještačenje, profesionalnu rehabilitaciju i zapošljavanje osoba s invaliditetom. Imajući u vidu ovakvu zakonsku mogućnost za roditelje djece s teškoćama u razvoju, možemo razumjeti dobivene rezultate koji upućuju na zaključak da nema značajne razlike u kvaliteti obiteljskog funkcioniranja u obiteljima djece s teškoćama u razvoju u odnosu na obitelji djece normativnog razvoja. U SAD-u roditelji djece $s$ teškoćama u razvoju nemaju ovakav zakonski reguliran sustav socijalne podrške te su zbog toga izloženi puno većem stresu. Kako briga o djetetu $\mathrm{s}$ teškoćom u razvoju zahtjeva puno dodatne njege tako i rastu troškovi te su roditelji izloženi velikom financijskom stresu, što bitno smanjuje kvalitetu for parents because of the cost of additional care, and they need flexible working hours, resulting in missed business opportunities (Whiting, 2014). The problem for parents, amongst other things, is that they are not only mothers and fathers to their children, but also become physical therapists and nurses and have many roles, unlike the parents of children of normative development (Whiting, 2014). The same author concludes that the challenges faced by parents of children with disabilities result in negative consequences for their physical and mental health and therefore contribute to a significantly lower quality of family functioning. The results of the study of Milić Babić (2012) suggest that parents of children with disabilities who rate parental stress as high also rate family cohesiveness as low, as an indicator of family functioning. On the other hand, some authors conclude that the quality of family functioning in families of children with disabilities is equal to the quality of family functioning in families of children of normative development or may even be higher (Sobsey, 2004), as our results indicate. The reasons for these differences in the results can be found in the fact that they were obtained in different social systems. Specifically, the study conducted by Whiting (2014) was conducted in the United States. The social support system in the USA is significantly weaker than that in the Republic of Croatia. According to the Law on Maternity and Parental Aid of the Republic of Croatia, a parent of a child with a developmental disability is allowed to have the right to child care leave after the expiration of the right to maternity leave until the child is 8 years old. Also, according to this Law, one of the parents has the right to work part-time and to continue exercising this right after the child turns 8 , i.e. for as long as this need persists, based on the findings and opinion of the Institute for Expertise, Vocational Rehabilitation and Employment of Persons with Disabilities. Considering this legal possibility for parents of children with disabilities, we can understand the results obtained, which suggest that there is no significant difference in the quality of family functioning in families of children with disabilities in relation to families of children of normative development. In the United States, parents of children with disabilities do not have this statutory social support system and are therefore much more stressed. As caring for a disabled child requires a lot of extra care, so do the costs, and parents are exposed to great financial stress, which significantly reduces the quality of family functioning. 
obiteljskog funkcioniranja. Snažan individualizam koji je prisutan u SAD-u može biti još jedan razlog različitih rezultata. Naime od pojedinca se očekuje da se isključivo sam brine i rješava svoje teškoće i probleme te da ne traži i ne očekuje pomoć od uže ni od šire društvene zajednice. Za razliku od SAD-a u Republici Hrvatskoj još uvijek nije toliko prisutan individualizam i pojedinac očekuje i traži pomoć od društvene zajednice što mu pomaže da se lakše nosi s problemima i stresom u životu. Dakle po pitanju kvalitete obiteljskog funkcioniranja istraživanja donose različite zaključke, pa su potrebna daljnja istraživanja kako bi se dobila jasnija slika.

Četvrti problem bio je utvrditi postoje li razlike u procjeni kvalitete obiteljskog funkcioniranja između majki i očeva. Unatoč očekivanjima da će majke biti manje zadovoljne obiteljskim funkcioniranjem jer preuzimaju veću odgovornost i imaju veća očekivanja, ova hipoteza nije potvrđena. Čini se da se roditeljska uloga majke i očeva mijenja te da današnji očevi preuzimaju znatno više roditeljskih uloga negoli je to bilo ranije. Njihovo sudjelovanje u odgoju djece znatno se mijenja u smjeru njihove veće uključenosti, podjele kućanskih poslova (Cvrtnjak i Miljević-Riđički, 2013) što svakako pridonosi i podjednakoj procjeni obiteljskog funkcioniranja.

Sljedeći problem bio je utvrditi imaju li obitelji djece normativnog razvoja dostupniju socijalnu podršku obitelji i prijatelja od obitelji djece s teškoćama u razvoju. Pretpostavili smo da će obitelji djece normativnog razvoja imati višu razinu socijalne podrške od obitelji djece s teškoćama u razvoju. Dobiveni rezultati ukazuju da roditelji djece s teškoćama doživljavaju nešto malo, ali ne i statistički značajno manje obiteljske podrške, dok im je značajno manje dostupna podrška prijatelja. Ovakav rezultat u skladu je s nekim drugim istraživanjima koji pokazuju da roditelji djece s teškoćama imaju manje socijalne podrške (Webster, Majnemer, Plat i Shevell, 2008). Smatra se da kvaliteta bračnog odnosa ima veći utjecaj na roditeljstvo nego vanjski izvori društvene podrške (Belsky, 1984.) iako to nije slučaj kad je riječ o procjeni roditeljske efikasnosti kod očeva (Kersh i sur., 2006.). Naime očevi koji imaju veću socijalnu podršku svoje roditeljske kompetencije procjenjuju
The strong individualism present in the USA may be another reason for the different results. Specifically, an individual is expected to care for him- or herself and to solve his or her own difficulties and problems, and not to seek or expect help from a narrower or wider community. Unlike in the USA, individualism is still not so present in the Republic of Croatia and the individual expects and seeks help from the community, which helps him or her cope more easily with problems and stress in life. Thus, regarding the quality of family functioning, research draws different conclusions, making further research needed to obtain a clearer picture.

The fourth problem was to determine whether there were differences in the assessment of the quality of family functioning between mothers and fathers. Despite the expectation that mothers would be less satisfied with family functioning because they take on more responsibility and have higher expectations, this hypothesis was not confirmed. It seems that the parental role of mother and father is changing and that today's fathers are taking on significantly more parental roles than they were before. Their participation in the upbringing of children changes significantly in the direction of their greater involvement and division of household chores (Cvrtnjak and MiljevićRiđički, 2013), which certainly helps explain why mothers and fathers rate family functioning similarly.

The next question was to determine whether families of children with normative development had more accessible social support from family and friends than families of children with disabilities. We hypothesised that families of children with normative development would have a higher level of social support than families of children with disabilities. The results indicate that parents of children with disabilities experience slightly less, but not significantly less, family support, while experiencing significantly less available support from friends. This result is in line with some other studies showing that parents of children with disabilities have less social support (Webster, Majnemer, Plat, \& Shevell, 2008). Marital relationships are thought to have a greater impact on parenting than external sources of social support (Belsky, 1984), although this is not the case when assessing parental effectiveness in fathers (Kersh et al., 2006). Specifically, fathers who have greater social support rate their parenting competence better. Generally, fathers have a greater need for support 
boljima. Općenito, očevi imaju veću potrebu za podrškom (Martinac Dorčić i Ljubešić, 2008). Rezultati našeg istraživanja ne ukazuju na razlike u procjeni socijalne podrške obitelji, dok je znatno manje podrške prijatelja kod roditelja djece $\mathrm{s}$ teškoćama. Jedan od razloga za ovakav rezultat je možda u tome što roditelji djece s teškoćama u razvoju imaju više brige oko djeteta s obzirom na njegovu poteškoću te im tako ostaje manje vremena za društveni život i interakciju s drugim ljudima. Možda zbog toga što imaju više brige oko djeteta samo percipiraju da imaju manje podrške jer im je zbog svakodnevne dodatne njege djeteta život teži pa to utječe na percepciju brige. Također možemo pretpostaviti da se roditelji djece s teškoćama više oslanjaju na podršku specijaliziranih institucija umjesto da traže podršku obitelji i prijatelja.

Posljednje istraživačko pitanje odnosilo se na ispitivanje razlike u procjeni socijalne podrške obitelji i prijatelja kod majki i očeva. Majke izvješćuju o većoj raspoloživosti prijateljske podrške u odnosu na očeve. Procjena raspoloživosti podrške obitelji podjednaka je kod majki i očeva. Ovakav rezultat ide u prilog nalazima u području socijalizacije. Naime, žene lakše dijele različite teme pa tako i probleme sa svojim prijateljicama. One se povjeravaju, traže pomoć i podršku pa je stoga i dobiju, za razliku od muškaraca koji se češće zatvaraju u svoje probleme i teško ih dijele s drugima, što posredno znači i manju dostupnost prijateljske podrške (Klarin, 2006).

U svakom slučaju partnerska je podrška od primarne važnosti za obiteljsko funkcioniranje. Roditeljima djece s teškoćama u razvoju, tj. supružnik je najvažniji i najčešći izvor emocionalne, savjetodavne i praktične podrške. Žene koje primaju podršku svog supružnika psihički su zdravije od onih koje nemaju tu potporu. Brižan partner trebao bi podijeliti odgovornost u podizanju djece te uvijek biti u blizini kada nastane problem.

Čini nam se važnim istaknuti da bi fokus istraživača trebao biti usmjeren na istraživanje kvalitete bračne veze $u$ obiteljima djece $s$ teškoćama $u$ razvoju jer dijete $s$ teškoćama u razvoju sigurno nije jedini uzrok koji negativno utječe na dobrobit roditelja (Kersh i sur., 2006).
(Martinac Dorčić \& Ljubešić, 2008). The results of our study do not indicate differences in the assessment of family social support, whereas there is significantly less support from friends of parents of children with disabilities. One of the reasons for this result may be that parents of children with disabilities have more concern about their child because of their difficulty, leaving them less time for social life and interaction with other people. Perhaps because they need to care more about the child, they only perceive that they have less support, because their daily extra child care makes their lives more difficult, which affects the perception of care. We could also assume that parents of children with disabilities are more reliant on, and seek the support of, specialised institutions rather than seeking the support of family and friends.

The last research question concerned testing the difference in the assessment of social support of family and friends by mothers and fathers. Mothers report greater availability of friendly support compared to fathers. The assessment of the availability of family support is the same for mothers and fathers. This result supports the findings in the field of socialisation. Namely, women find it easier to share different topics, including problems with their friends. They confide in each other, ask for help and support and therefore receive it, unlike men who are more often locked in their problems and find it difficult to share them with others, which indirectly means less availability of friendly support (Klarin, 2006).

In any case, partner support is of primary importance for family functioning. For parents of children with disabilities, the spouse is the most important and common source of emotional, counseling and practical support. Women who receive the support of their spouse are psychologically healthier than those who do not have such support. A caring partner should share responsibility in raising children and always be around when a problem arises.

It seems important to point out that the focus of the researchers in this field should be on examining the quality of the marital relationship in families of children with disabilities, since a child with disabilities is certainly not the only cause of negative effects for the well-being of parents (Kersh et al., 2006).

The results of our study show that families with children with disabilities are generally perceived 
Rezultati našeg istraživanja pokazali su kako obitelji djece s teškoćama u razvoju načelno sigurnost u bliskim odnosima procjenjuju slabijom što upućuje na zaključak o narušenosti osjećaja sigurnosti. Također majke iz obitelji koje imaju dijete s teškoćama imaju naglašeniju potrebu za interpersonalnom blizinom, ljubavi i potporom u odnosu na očeve iz takvih obitelji. Na koncu roditelji koji imaju dijete s teškoćama u razvoju dostupnost prijatelja procjenjuju manjom u odnosu na roditelje koji imaju dijete normativnog razvoja, dok je dostupnost obitelji također slabija, ali rubno.

Nema sumnje da je briga o djetetu s teškoćom u razvoju posebno izazovna za roditelje i da ona do maksimuma ispituje njihove mentalne, fizičke i financijske granice. Takva briga zahtijeva puno žrtve i odricanja, ali i puno prilagođavanja u kojem će roditelji puno svojih planova, ambicija i želja staviti u drugi plan. Drugi dio literature zaključuje da obitelji djece s teškoćama u razvoju imaju kvalitetu obiteljskog funkcioniranja koja je jednaka, a ponekad čak i bolja nego u obitelji djece normativnog razvoja (Sobsey, 2004). Rezultati ovog istraživanja na tragu su zaključaka tog dijela znanstvene literature. Postavlja se pitanje kako razumjeti ovako oprečne zaključke. Možemo pretpostaviti da u onim obiteljima u kojima je kvaliteta obiteljskog funkcioniranja bila dobra prije rođenja djeteta s teškoćom, rođenjem djeteta ona se nije pokvarila, dok s druge strane u onim obiteljima gdje su postojali problemi od prije rođenja djeteta $\mathrm{s}$ teškoćom u razvoju, ti su problemi dodatno eskalirali (Sobsey, 2004).

Doprinos ovog istraživanja vidimo u tome što je ova tema vrlo rijetko zastupljena u znanstvenoj literaturi. Nadalje ispitivanje privrženosti u bliskim odnosima varijabla je koja se, koliko je nama poznato, do sada nije ispitivala u kontekstu ove teme.

Ograničenja ovog istraživanja svakako se odnose na uzorak. Naime mali broj sudionika istraživanja otežava generalizaciju. Nadalje u istraživanju su sudjelovali roditelji koji su to htjeli što je pridonijelo selektivnosti uzorka. Drugim riječima uzorak nije probabilistički. Kriterij za sudjelovanje u istraživanju bila je dob djeteta, spol djeteta i dobrovoljnost. Također unatoč tome što je uzorak prigodan, možemo pretpostaviti da ove dvije to be less secure in close relationships, suggesting a disrupted sense of security. Also, mothers from families with a child with disabilities have a greater need for interpersonal closeness, love and support than fathers from such families. In the end, parents with a child with disabilities rate the availability of friends as lower than parents who have a child of normative development, while family availability is also lower, but only marginally.

There is no doubt that caring for a disabled child is particularly challenging for parents and that it puts their mental, physical and financial boundaries to a test. Such care requires a lot of sacrifice but also a lot of adjustment in which parents will set aside a lot of their plans, ambitions and desires. Another part of the literature concludes that families of children with disabilities have a quality of family functioning that is equal, and sometimes even better, in comparison to the families of children of normative development (Sobsey, 2004). The present study is consistent with this latter stream of research: family functioning was similar between the two groups of families. The question is how to understand such conflicting conclusions. We can assume that in those families where the quality of family functioning was good before the birth of a child with a disability, the birth of the child did not deteriorate it, while, on the other hand, in those families where there were problems before the birth of a child with a disability, these problems further escalated (Sobsey, 2004).

We see the contribution of this research in the fact that this topic is very rare in the scientific literature. Furthermore, the examination of attachment in close relationships is a variable that, as far as we know, has not been examined so far in the context of this topic.

The limitations of this research certainly relate to the sample. Namely, the small number of research participants makes it difficult to generalise the conclusions drawn from the research results. Furthermore, parents who wished to do so participated in the study, which contributed to the selectivity of the sample. In other words, the sample was not probabilistic. The criteria for participation in the study were the age of the child, the sex of the child and voluntary participation. Also, since the sample was convenient, we can assume that these 
skupine roditelja nisu izjednačene s obzirom na relevantne čimbenike koji pridonose kvaliteti bliskih odnosa i obiteljskog funkcioniranja kao što su financijski status, broj djece u obitelji, dob roditelja i radni status što bi buduća istraživanja svakako trebala uzeti u obzir. two groups of parents were not equal with regard to relevant factors that contribute to the quality of close relationships and family functioning such as financial status, number of children in the family, age of parents and employment status, which should definitely be considered in future research. 


\section{LITERATURA/ LITERATURE}

Baker, B. L., Blacher, J., Olsson, M., B. (2005). Preschool children with and without developmental delay: behaviour problems, parents' optimism and well- being. Journal of Intellectual Disability Research 49, 575- 590. Blackwell Publishing Ltd.

URL: https://escholarship.org/content/qt4mm984n5/qt4mm984n5.pdf (29.04.2019.)

Baker, B. L., McIntyre, L. L., Blacher, J., Crnic, J., Edelbrock, C., Low, L. (2003). Preschool children with and without developmental delay: Behaviour problems and parenting stress over time. Journal of Intellectual Disability Research 47, 217-230. Blackwell Publishing Ltd.

Belsky, J. (1984). The determinants of parenting: a process model. Child development, 55(1), 83-96.

Bleacher, J., Shapiro, J., Lopez, S., Diaz, L. (1997). Depression in Latina mothers of children with mental retardation: A neglected concern. Family Relations. 46/ 4, Family Caregiving for Persons with Disabilities, pp. 325-334. DOI: $10.2307 / 585093$.

Bluth,K., Roberson, P. N. E., Billen, R. M. Sams, J. M. (2013). A Stress Model for Couples Parenting Children With Autism Spectrum Disorders and the Introduction of a Mindfulness Intervention. Journal of Family Theory Review, $5(3), 194-213$.

Bristol, M. M., Gallagher, J. J., Schopler, E. (1988.). Mothers and fathers of young developmentally disabled children and nondisabled boys: Adaptation and spousal support. Developmental Psychology, 24(3), 441 - 451. DOI:10.1037/0012-1649.24.3.441

Calogero, I., Pellerone, M., Pacea, U., Ramacia, T., Castorina, V. (2016). Family Functioning and Disability: a Study on Italian Parents of Disabled Children. The European Proceedings of Social \& Behavioural Science EpSBS, http://dx.doi.org/10.15405/epsbs.2016.05.5

Cuzzocrea, F., Larcan, R., Baiocco, R., Costa, S. (2011). Family functioning, parenting, and couple satisfaction in families of children with disability. Disability and the Family, 16(2), 7-24.

Cuzzocrea, F., Larcan, R., Westh, F. (2013). Family and parental functioning in parents of disabled children. Nordic Psychology 65:3, 271-287.

Cvrtnjak, I., Miljević-Riđički, R. (2013). Očevi nekad i danas [Fathers in the past and today]. Teorijski i praktični problemi i rasprave, 113-122.

Esdaile, S.A., Greenwood, K.M. (1995). A survey of mothers' relationship with their preschoolers. Occupational Therapy International 2: 204-21.

Esdaile, S. A., Greenwood, K. M. (2003). A comparison of mothers' and fathers' experience of parenting stress and attributions for parent-child interaction outcomes. Occupational Therapy International 10(2), 115-126. Whurr Publishers Ltd.

Ha, J., Greenberg, J. S., Seltzer, M. M. (2011). Parenting a Child With a Disability: The Role of social Support for African American Parents. Families in Society,92, 4, 405-411.

Hartley, S. L., Mailick Seltzer, M., Barker, E. T., Greenberg, J. S. (2011). Marital Quality and Families of Children with Developmental Disabilities. International Review of Research in Developmental Disabilities 41, 1-29.

Heiman, T. (2002). Parents of children with disabilities. Resilience, coping and future expectations. Journal of Developmental and Physical Disabilities, 14, 159-171. doi:10.1023/A:1015219514621

Hornby, G. (1992). A review of fathers' accounts of their experiences of parenting children with disabilities. Disability, Handicap, and Society, 7(4), 363-374.

Ivanov, L. (2010). Skala socijalne podrške [Social Support Scale]. In: I. T. Junaković, V. Ćubela Adorić, Z. Penezić, A. Proroković (Eds.). Zbirka psihologijskih skala i upitnika [Collection of psychological scales and questionnaires] (pp. 69-77). Zadar: University of Zadar. 
Kersh, J., Hedvat, T. T., Hauser- Cram, P., Warfield, M. E. (2006). The contribution of marital quality to the well- being of parents of children with developmental disabilities. Journal of Intellectual Disability Research, 50, 883- 893.

Klarin, M. (2006). Razvoj djece u socijalnom kontekstu - roditelji, vršnjaci, učitelji - kontekst razvoja djeteta [Children's development in a social context - parents, peers, teachers - the context of a child's development]. Jastrebarsko: Naklada Slap.

Lamb, M. E., Billings, L. A. L. (1997). Fathers of children with special needs. In: M. E. Lamb (Ed.), The role of the father in child development (pp. 179-190). New York: John Wiley \& Sons.

Leutar, Z., Starčić, T. (2007). Partnerski odnosi i dijete s poteškoćama u razvoju [Partner relationships and a child with developmental disabilities]. Annual of social work, 14(1), 27-58. URL: https://hrcak.srce.hr/11493 (10.08.2019.)

Leurar, Z., Oršulić, V. (2015). Povezanost socijalne podrške i nekih aspekata roditeljstva u obiteljima s djecom s teškoćama u razvoju [Relationship between social support and some aspects of parenting in families with children with disabilities]. Croatian Journal of Social Policy, 22(2), 153-176.

Martinac Dorčić, T., Ljubešić, M. (2008). Psihološka prilagodba roditelja na dijete s kroničnim bolestima [Psychological adjustment of parents to a child with chronic illness], Društvena istraživanja: Journal for General Social Issues, 6(104), 1107-1129.

Milić Babić, M. (2012). Obiteljska kohezivnost u obiteljima djece s teškoćama u razvoju [Family cohesiveness in families of children with disabilities], New presence: Review for intellectual and spiritual questions, 2, 207-224.

Ombla, J., Jurkin, M. (2014). Skala privrženosti kao stanja [The State Attachment Scale]. In: V. Ćubela Adorić, Z. Penezić, A. Proroković, I. T. Junaković (Eds.). Zbirka psihologijskih skala i upitnika [Collection of psychological scales and questionnaires] (pp. 21 - 28). Zadar: University of Zadar.

Raj Gogoi, R., Kumar, R., Pereira Deuri, S. (2016). Anxiety, depression, and quality of life in mother of children with intellectual disability. Open Journal of Psychiatry and Allied Sciences 8, 1, 71-75.

Quinn, P. (1999). Supporting and encouraging father involvement in families of children who have a disability. Child and Adolescent Social Work Journal, 16(6), 439-454.

Scherer, N., Verhey, I.,Kuper, H. (2019). Depression and anxiety in parents of children with intellectual and developmental disabilities: a systematic review and meta-analysis. PLoS ONE 14(7): e0219888. https://journals. plos.org/plosone/article/comments?id=10.1371/journal.pone.0219888

Sobsey, D. (2004). Marital stability and marital satisfaction in families of children with disabilities: Chicken or egg?. Developmental Disabilities Bulletin, 32 (1), str. 62 - 83.

Šimunić, A., Gregov, Lj. (2010). Skala kvalitete obiteljskog funkcioniranja [Scale of the Quality of Family Functioning]. In: I. T. Junaković, V. Ćubela Adorić, Z. Penezić, A. Proroković (Eds.). Zbirka psihologijskih skala i upitnika [Collection of psychological scales and questionnaires] (pp. 31- 37). Zadar: University of Zadar.

Wanamaker, C. E., Glenwick, D. S. (1998). Stress, coping, and perceptions of child behavior in parents of preschoolers with cerebral palsy. Rehabilitation Psychology, 43(4), 297-312. doi:10.1037/0090-5550.43.4.297

Webster, R.I., Majnemer, A., Platt, R.W., Shevell, M.I. (2008). Child health and parental stress in school-age children with a preschool diagnosis of developmental delay. Journal of Child Neurology, 23-1, 32-38.

Whiting, M. (2014). Children with disability and complex health needs: The impact on family life. Nursuing children and young people 26(3), $26-30$.

Legal source

Pravilnik o osnovnoškolskom odgoju i obrazovanju učenika s teškoćama u razvoju. Narodne novine 23/91.

Zakon o rodiljnom i roditeljskim potporama [Maternity and Parental Aid Act]. Narodne novine, 85/08, 110/08,34/11, $54 / 13,152 / 14,59 / 17$. 